\title{
Equilibrium studies on the uptake of nitrate and phosphate ion onto low-cost adsorbent prepared via radiation-induced graft polymerization and hydrazine hydrate functionalization
}

CHUKWUNONSO ANIAGOR ( $\square$ co.aniagor@unizik.edu.ng )

Nnamdi Azikiwe University https://orcid.org/0000-0001-6488-3998

H.H. Sokker

National Center for Radiation Research and Technology

A.I. Hashem

Ain Shams University

Y.M. El-Hamaki

Ain Shams University

M.H. El-Degwi

Admiral Co.

E.S. Abdel-Halim

National Research Centre

A. Hashem

National Research Centre

Research Article

Keywords: Adsorption, cellulosic-fabrics, nitrate ion, phosphate ion, isotherm

Posted Date: April 21st, 2021

DOI: https://doi.org/10.21203/rs.3.rs-440004/v1

License: (c) (i) This work is licensed under a Creative Commons Attribution 4.0 International License.

Read Full License 
Equilibrium studies on the uptake of nitrate and phosphate ion onto low-cost adsorbent prepared via radiation-induced graft polymerization and hydrazine hydrate functionalization

Chukwunonso .O. Aniagor ${ }^{a *}$, H.H. Sokker ${ }^{\mathrm{b}}$, A.I. Hashem ${ }^{\mathrm{c}}$, Y.M. El-Hamaki ${ }^{\mathrm{c}}$, M.H. El-Degwid ${ }^{\text {, E.S. Abdel-Halim }}{ }^{\mathrm{e}}$, A. Hashem ${ }^{\mathrm{e} * *}$

${ }^{a}$ Department of Chemical Engineering, Nnamdi Azikiwe University, P.M.B. 5025, Awka, Nigeria.

${ }^{b}$ National Center for Radiation Research and Technology, Nasr City, Cairo, Egypt.

${ }^{c}$ Faculty of Science-Ain Shams University, Cairo, Egypt.

${ }^{\mathrm{d} A d m i r a l ~ C o ., ~ C a i r o, ~ E g y p t . ~}$

${ }^{\mathrm{e} N a t i o n a l ~ R e s e a r c h ~ C e n t r e, ~ D i k k o, ~ C a i r o, ~ E g y p t . ~}$

*Corresponding authors' e-mail: co.aniagor@unizik.edu.ng

**Corresponding authors' e-mail: alihashem2000@yahoo.com

\title{
ORCID
}

A. Hashem: https://orcid.org/0000-0001-7981-4872

C.O. Aniagor: http://orcid.org/0000-0001-6488-3998

\section{Highlights}

- Adsorption of $\mathrm{NO}_{3}{ }^{-}$and $\mathrm{PO}_{4}{ }^{3-}$ anions onto functionalized cellulosic fabric waste was presented.

- The extent of copolymer grafting depends on the monomer concentration and irradiation dose.

- The surface chemistry and morphology of the adsorbent was elucidated by FTIR and SEM studies

- In-depth isothermal studies using eight (8) nonlinear models were performed.

\begin{abstract}
In the study, cellulosic fabric waste-based anion exchanger ('Cell-AE'), with abundant $\mathrm{N}^{+}\left(\mathrm{CH}_{3}\right)_{2}$ functional groups were prepared by graft copolymerization of acrylonitrile (AN) onto cotton fabric waste using $\gamma$ radiation ${ }^{60} \mathrm{Co}$, followed by chemical modification with hydrazine hydrate and alkylation with dimethyl sulfate. Factors affecting the grafting process, such as radiation dose and monomer concentration, was investigated. The main adsorbent ( ' $\mathrm{Cell}-\mathrm{AE}$ ') and its intermediate precursors were characterized using Fourier transform infrared spectroscopy (FTIR) and scan electron microscopy (SEM). The nitrate and phosphate sorption potentials of the Cell-AE further evaluated via batch mode. Based on the results obtained, 'Cell-AE' showed higher adsorption affinity towards phosphate ion $(19.56 \mathrm{mg} / \mathrm{g})$, when compared to that of the nitrate ion $(11.23 \mathrm{mg} / \mathrm{g})$. Similarly, the phosphate and nitrate ion
\end{abstract}


adsorption onto 'Cell- $A E$ ' obeys both Dubinin-Radushkevich (D-R) and Redlich-Peterson (RP) isotherm models, respectively. The present study conclusively proffered a potential mitigation approach to cotton fabric waste management.

Keyword: Adsorption; cellulosic-fabrics; nitrate ion; phosphate ion; isotherm

\section{Introduction}

Freshwater, including rivers, lakes and groundwater represents about $2.66 \%$ of the whole global water resources, of which only about $0.6 \%$ is suitable for drinking [1]. As the global population increases, the global demand for freshwater increases and therefore, it is top necessary to treated water reserves and wastewater carefully to overcome the increasing water demand [2]. Chemical compounds composed of phosphate or nitrate group are among the leading freshwater pollutants. They find their ways into the aquatic environment, mostly due to the unwholesome wastewater discharge habits of process industries and could significantly upset the natural biological balance of living organisms present and affecting the water quality $[3,4]$. Water eutrophication is a form of water pollution of global concerns [5]. Although nitrate $\left(\mathrm{NO}_{3}{ }^{-}\right)$and phosphate $\left(\mathrm{PO}_{4}{ }^{3-}\right)$ are important nutrients for the flourishing of plants and many other unicellular organisms, they still rank among the prominent nutrients responsible for this freshwater eutrophication [5].

The issue of eutrophication subsists when nitrate and phosphate laden waste streams from varying sources (such as, fertilizer production plant, septic tanks, atmospheric deposition, etc) is discharged into the aquatic environment in concentrations that exceeds the relevant permissible limits [6]. The presence of a high concentration of these pollutants in watercourses could ultimately cascade into several harmful ecological effects [7, 8]. A significant reduction of oxygen level due to eutrophication can be very detrimental to aquatic life in general and results in reduced biodiversity [9]. Also, excessive ingestion of nitrate $\left(\mathrm{NO}_{3}{ }^{-}\right)$ion contaminated water often results in blue baby syndrome, a disease caused due to nitrate binding with haemoglobin. Phosphate and nitrate pollution can also have a severe effect on the renewability of natural resource [10-12]. Hence, WHO stipulated permissible drinking water limits of 40 and $<0.5 \mathrm{mg} \mathrm{L}^{-1}$ for $\mathrm{NO}_{3}{ }^{-}$and $\mathrm{PO}_{4}{ }^{3-}$ contamination, respectively [13].

Considering the aforementioned negative implications of phosphate and nitrate pollution, their removal from the waste stream is imperative. To this end, several phosphate and nitrate removal techniques such as chemical precipitation [14], adsorption [15], reverse osmosis [16], 
biological removal [17], electrodialysis [18] have been investigated. Furthermore, some of these techniques are technologically driven and expensive in the context of developing countries. For instance, enhanced biological treatment has depicted up to $97 \%$ phosphate removal [19], but the variation in the effluent chemical composition and temperature limits their full-scale implementation. Similarly, the high operational cost and process inefficiency associated with the application of electrodialysis and reverse osmosis has also been highlighted [19]. However, the adsorption technique has been commonly applied due to its operational flexibility and economics, as well as low sludge generation [20, 21]. Also, the spent adsorbent could have agricultural application as a phosphate fertilizer and soil conditioner [22].

Native cellulosic fibres, one of the most abundant renewable raw material, with great industrial applications. However, their lack of thermo-plasticity, poor dimensional stability and poor crease-resistance retard their adsorption performance properties [23]. These properties can be improved by subjecting the cellulosic fabric to different chemical modifications for example grafting of different monomers to the cellulosic chain or etherification reaction [2432]. Other performance properties, like thermal stability and resistance to biological and chemical agents, can also be improved through chemical modification and consequently applied as an absorbent in wastewater purification [33-38], ion-exchangers for the removal of metal cations from aqueous solutions [39-44], etc. Weakly basic anion exchangers contain primary, secondary, tertiary or quaternary amino groups in their chemical structures [45-47]. Meanwhile, the basicity of the resins containing these amino groups can be enhanced by alkylation reaction, different agents like, dimethyl sulfate [48, 49].

Recently, the application of functionalized polymeric fibres as efficient adsorption for adsorbing varying pollutants have been on the rise [50-53]. This increasing interest is due to their (fibrous adsorbents) fast adsorption kinetics, which is linked to a reduced mass transfer resistance and molecular diffusional path during adsorption [54]. Vatutsina, et al [55] and Lin, et al [56] investigated the ion-exchange capacity of different functionalized polyacrylonitrile (PAN) and polypropylene (PP) fibres. Their work underscored the adsorption effectiveness of these functionalized fibres. Furthermore, PAN fibre-based adsorbent obtained from a 2-stage synthesis procedure of crosslinking and base-catalyzed hydrolysis step was successfully employed for the adsorption of organic amine [57]. Consequently, the application of hydrazine hydrate $(\mathrm{HH})$ and other polyamines as organic crosslinkers have been reported used for crosslinking $[58,59]$. 
Therefore, the current study aims at grafting acrylonitrile (AN) onto cotton fabric, followed by reaction with hydrazine hydrate and finally alkylation with dimethyl sulfate. The synthesized adsorbent (Cell-AE) was further applied for removing phosphate and nitrate anions from their aqueous solutions. The effect of the process variable on the anion removal was investigated, while the adsorbent properties were characterized using Fourier transform infrared spectroscopy (FTIR) and scanning electron microscopy (SEM).

\section{Experimental}

\subsection{Materials and chemicals}

Scoured and bleached plain weave cotton fabrics, in the form of tailoring process wastes were kindly supplied Miser Company for Spinning and Weaving, EL-Mahala, Egypt. Acrylonitrile (AN), styrene and dihydrogen sodium phosphate supplied were by Merck (Germany). Hydrazine hydrate was supplied by Sisco Research Laboratories, Mumbai, India. Dimethyl sulfate was supplied by LOBA CHEMIE PVT, LTD. Mumbai, India. Aluminium nitrate was supplied by Al-Gomhoria Company Cairo, Egypt.

\subsection{Synthesis of adsorbent}

Poly-(acrylonitrile)-grafted cellulose was prepared via radiation-induced polymerization reaction. The grafting reaction was carried out in a pyrex tube containing the monomer dissolved in DMF, together with a definite weight of the cellulosic fabric and $5 \%$ styrene (based on monomer weight) as an inhibitor. The reaction was carried out using $\gamma$-rays of ${ }^{60} \mathrm{Co}$ source at different radiation doses. The grafted cotton fabric was removed from the Pyrex tube, washed thoroughly with DMF, then several times with distilled water to remove the homopolymer from the grafted cotton fabric, and then the grafted fabric was dried and weighed. The degree of grafting was calculated as a percentage increase in the fabric weight following Eq. (1).

$G \%=\left[\left(\frac{W_{g}-W_{o}}{W_{o}}\right) * 100\right]$

Where $\mathrm{W}_{\mathrm{o}}$ and $\mathrm{W}_{\mathrm{g}}$ represent the weight of original and grafted cotton fabrics, respectively. The grafted cotton fabric $(10 \mathrm{~g})$ was modified via treatment with hydrazine hydrate/methanol mixture $(33: 160 \mathrm{~mL})$ in a reactor equipped with a magnetic stirrer under reflux condition, at 80 ${ }^{\circ} \mathrm{C}$ for $20 \mathrm{~h}$. The modified cotton fabric was washed thoroughly with ethanol and dried at 60 ${ }^{\circ} \mathrm{C}$. The so obtained functionalized fabric was further modified through alkylation with 
dimethyl sulfate at $10{ }^{\circ} \mathrm{C}$ in the presence of $\mathrm{NaOH}$ for $3 \mathrm{~h}$, then finally washed with ethanol and dried.

\subsection{Adsorption study}

$100 \mathrm{~mL}$ of the respective anion solutions (aluminium nitrate. $9 \mathrm{H}_{2} \mathrm{O}$ and dihydrogen sodium phosphate) in the concentration range of $50-250 \mathrm{mg} \mathrm{L}^{-1}$, was drained separately into different $125 \mathrm{~mL}$ Erlenmeyer flasks containing $0.1 \mathrm{~g}$ each. The $\mathrm{pH}$ of the adsorbate solution contained in the respective flasks was adjusted to the desired value using $0.1 \mathrm{M} \mathrm{HNO}_{3}$ or $0.1 \mathrm{M} \mathrm{NaOH}$ solutions. The Erlenmeyer flasks and their contents were then agitated at a constant speed of $150 \mathrm{rpm}$ for a predetermined time interval at a fixed temperature. At the end of the agitation cycle, the 'cell- $A E$ ' was immediately obtained as filtrate from the adsorbate solutions. The above procedure was repeated as blank experiments (in the absence of 'cell-AE'). The quantity of the respective anions adsorbed onto the 'cell- $A E$ ' surface was determined using ion chromatograph ICDX 100 IM Chromatography Dionex, USA and subsequently compared to the anion concentration in the corresponding blank flask. The percentage anionic removal and amount adsorbed at equilibrium, $\mathrm{q}_{\mathrm{e}}(\mathrm{mg} / \mathrm{g})$ was calculated using Eqs. (2) and (3).

Removal \% $=\frac{\mathrm{C}_{\mathrm{o}}-\mathrm{C}_{\mathrm{e}}}{\mathrm{C}_{\mathrm{o}}} \times 100 \%$

$q_{e}=\frac{\left(C_{o}-C_{e}\right) \cdot V}{W}$

Where, $\mathrm{C}_{\mathrm{o}}$ and $\mathrm{C}_{\mathrm{e}}\left(\mathrm{mg} \mathrm{L}^{-1}\right)$ are the initial and final anion concentrations, respectively. $\mathrm{V}(\mathrm{L})$ is anion solution volume and $\mathrm{W}(\mathrm{g})$ is the adsorbent fabric weight. For accuracy, the adsorption experiments were performed always in duplicate to get more accurate mean values for $\mathrm{q}_{\mathrm{e}}$.

\subsection{Instrumental characterizations}

The untreated, grafted and modified cotton fabrics were examined by Fourier Transform infrared spectroscopy (FTIR) to assign the vibrational frequencies of different functional groups present in their structures. The IR spectra of the samples were recorded using Mattson 1000 FTIR spectrophotometer (Unicom, England).

The scanning electron micrograph (SEM) test was conducted to characterize the morphology and surface properties of untreated, grafted and modified cotton fabric. The samples were mounted on a standard microscope stub and coated with a thin gold layer by use of a JEOL SEM 25 (Japan). 


\subsection{Adsorption modelling}

Insight into the adsorbate - adsorbent interaction during the adsorption process is obtained from adsorption isotherm modelling, while the various model parameters could inform the probable sorption mechanism $[2,60,61]$. The experimental equilibrium data generated from this study were modelled with nonlinear form of Langmuir [20, 62, 63], Freundlich [64-66], Temkin [67, 68], D-R [69, 70], Khan [71, 72], Redlich-Peterson [73, 74], Toth [75, 76] and Sips [72, 77] models. The mathematical expression of these isotherm models is presented in Table 1.

The nonlinear model goodness of data fit is usually evaluated from the magnitude of some dedicated goodness-of-fit (GO-Fm) models. The goodness of fit evaluation is made based on the following criteria: (i) the lower the error values for a given isotherm or kinetic model, the better the model fit, (ii) the larger the $\mathrm{R}^{2}$-value the better the model fit. The GO-Fm models applied in this work comprised of average relative error, ARE [78], average percentage error, APE [79], the sum of squared error, SSE [80], hybrid fraction error, HYBRID [81], Marquardt's Percent Standard Deviation, MPSD [78], Nonlinear chi-square test, $\chi^{2}$ [82] and Coefficient of determination, $\mathrm{R}^{2}$ [83]. The equation of these GO-Fm models is presented in Table 2.

Table 1: The isotherm model equations applied in the study

\begin{tabular}{|c|c|c|c|}
\hline \multicolumn{2}{|c|}{ 2-parameter models } & \multicolumn{2}{|c|}{ 3-parameter models } \\
\hline Model name & Model Equation & Model name & Model Equation \\
\hline Langmuir & $\mathrm{q}_{\mathrm{e}}=\frac{\mathrm{q}_{\mathrm{m}} \mathrm{k}_{\mathrm{L}} \mathrm{C}_{\mathrm{e}}}{1+\mathrm{k}_{\mathrm{L}} \mathrm{C}_{\mathrm{e}}}$ & Khan & $\mathrm{q}_{\mathrm{e}}=\frac{\mathrm{q}_{\mathrm{mK}} * \mathrm{~b}_{\mathrm{K}} * \mathrm{C}_{\mathrm{e}}}{\left(1+\mathrm{b}_{\mathrm{K}} * \mathrm{C}_{\mathrm{e}}\right)^{\mathrm{a}_{\mathrm{K}}}}$ \\
\hline Freundlich & $\mathrm{q}_{\mathrm{e}}=\mathrm{K}_{\mathrm{F}}\left(\mathrm{C}_{\mathrm{e}}\right)^{\frac{1}{\mathrm{n}_{\mathrm{F}}}}$ & $\mathrm{R}-\mathrm{P}^{*}$ & $\mathrm{q}_{\mathrm{e}}=\frac{\mathrm{A}_{\mathrm{RP}} \mathrm{C}_{\mathrm{e}}}{1+\mathrm{B}_{\mathrm{RP}} *\left(\mathrm{C}_{\mathrm{e}}\right)^{\mathrm{g}}}$ \\
\hline Tempkin & $\mathrm{q}_{\mathrm{e}}=\frac{\mathrm{RT}}{\mathrm{b}_{\mathrm{T}}} \ln \left(\mathrm{K}_{\mathrm{T}} \mathrm{C}_{\mathrm{e}}\right)$ & Sip & $\mathrm{q}_{\mathrm{e}}=\frac{\mathrm{K}_{\mathrm{s}} * \mathrm{C}_{\mathrm{e}}^{\beta_{1}}}{1+\mathrm{a}_{\mathrm{s}} * \mathrm{C}_{\mathrm{e}}^{\beta_{1}}}$ \\
\hline D-R* & $\exp \left\{-B_{D}\left[\operatorname{RT}\left(1+\frac{1}{C_{e}}\right)\right]^{2}\right\}$ & Toth & $\mathrm{q}_{\mathrm{e}}=\frac{\mathrm{k}_{\mathrm{T}} * \mathrm{C}_{\mathrm{e}}}{\left(\mathrm{a}_{\mathrm{T}}+\mathrm{C}_{\mathrm{e}}\right)^{\mathrm{t}^{-1}}}$ \\
\hline
\end{tabular}

*D-R = Dubinin-Radushkevich; R-P = Redlich-Peterson 
Table 2: The applied goodness-of-fit models

\begin{tabular}{|c|c|}
\hline Error Function & Equation \\
\hline Average Relative Error (ARE) & $A R E=\sum_{i=1}^{n}\left|\frac{\left(q_{e}\right)_{\text {exp. }}-\left(q_{e}\right)_{\text {calc. }}}{\left(q_{e}\right)_{\text {exp. }}}\right|$ \\
\hline Average Percentage Error (APE) & $A P E \%=\frac{\sum_{i=1}^{N} \mid\left[\left(\left(q_{e}\right)_{\text {exp. }}-\left(q_{e}\right)_{\text {calc. }}\right) / q_{\text {exp. }} . \mid\right.}{N} \times 100$ \\
\hline Sum Squares Error (ERRSQ/SSE) & $E R R S Q=\sum_{i=1}^{n}\left[\left(q_{e}\right)_{\text {calc. }}-\left(q_{e}\right)_{\text {exp. }}\right]^{2}$ \\
\hline Hybrid Fraction Error Function (Hybrid) & Hybrid $=\frac{100}{n-p} \sum_{i=1}^{n}\left[\frac{\left(\left(q_{e}\right)_{\text {exp. }}-\left(q_{e}\right) \text { calc. }\right)^{2}}{\left(q_{e}\right)_{\text {exp. }}}\right]_{i}$ \\
\hline $\begin{array}{l}\text { Marquardt's Percent Standard Deviation } \\
\text { (MPSD) }\end{array}$ & $M P S D=\left(\sqrt[100]{\frac{1}{n-p} \sum_{i=1}^{n}\left[\frac{\left(\left(q_{e}\right)_{\text {exp. }}-\left(q_{e}\right)_{\text {calc. }}\right)}{\left(q_{e}\right)_{\text {exp. }}}\right]^{2}}\right.$ \\
\hline Nonlinear chi-square test $\left(\chi^{2}\right)$ & $\chi^{2}=\sum \frac{\left(q_{e . \mathrm{exp}}-q_{\text {e.theoretical }}\right)^{2}}{q_{\text {e.theoretical }}}$ \\
\hline Coefficient of determination $\left(\mathrm{R}^{2}\right)$ & $R^{2}=\frac{\sum_{i=1}^{n}\left(q_{e, \text { calc }}-\overline{q_{e, \exp }}\right)^{2}}{\sum_{i=1}^{n}\left(q_{e, \text { calc }}-\overline{q_{e, \exp }}\right)^{2}+\sum_{i=1}^{n}\left(q_{e, \text { calc }}-q_{e, \exp }\right)^{2}}$ \\
\hline
\end{tabular}

\section{Results and Discussion}

\subsection{Adsorbent synthesis mechanism}

The suggested mechanism for the reaction of cotton fabric with acrylonitrile (AN), followed by hydrazine hydrate functionalization and final alkylation using dimethyl sulfate is discussed herein. The $\gamma$-rays catalyzed the amination of the cotton fabric with acrylonitrile (AN) to yield the aminated graft-cotton fibre (A-g-CF) as shown in Eq. (4). The subsequent reaction with the hydrazine hydrate (HH) shown in Eq. (5), occurred via the nucleophilic attack on the A-g-CF nitrile groups by the nitrogen lone pair of electron of the HH [84]. Similarly, Eq. (5) also represents a crosslinking reaction characterized by the bonding of the hydrazine molecules to adjacent polymer chains. Further alkylation of the hydrazine modified A-g-CF with dimethyl sulfate/ $\mathrm{NaOH}$ solution [Eq. (6)] converts the available nitrile groups to carboxamide, (which could further oxidize to carboxylate groups) and other important anion chelation sites via basecatalysed hydrolysis reactions. 


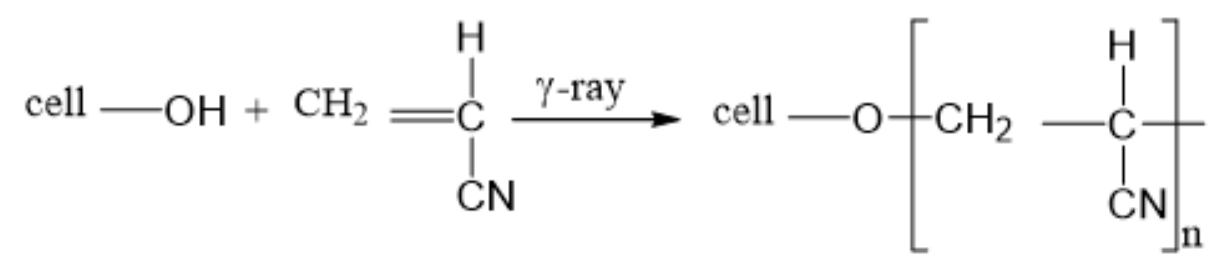
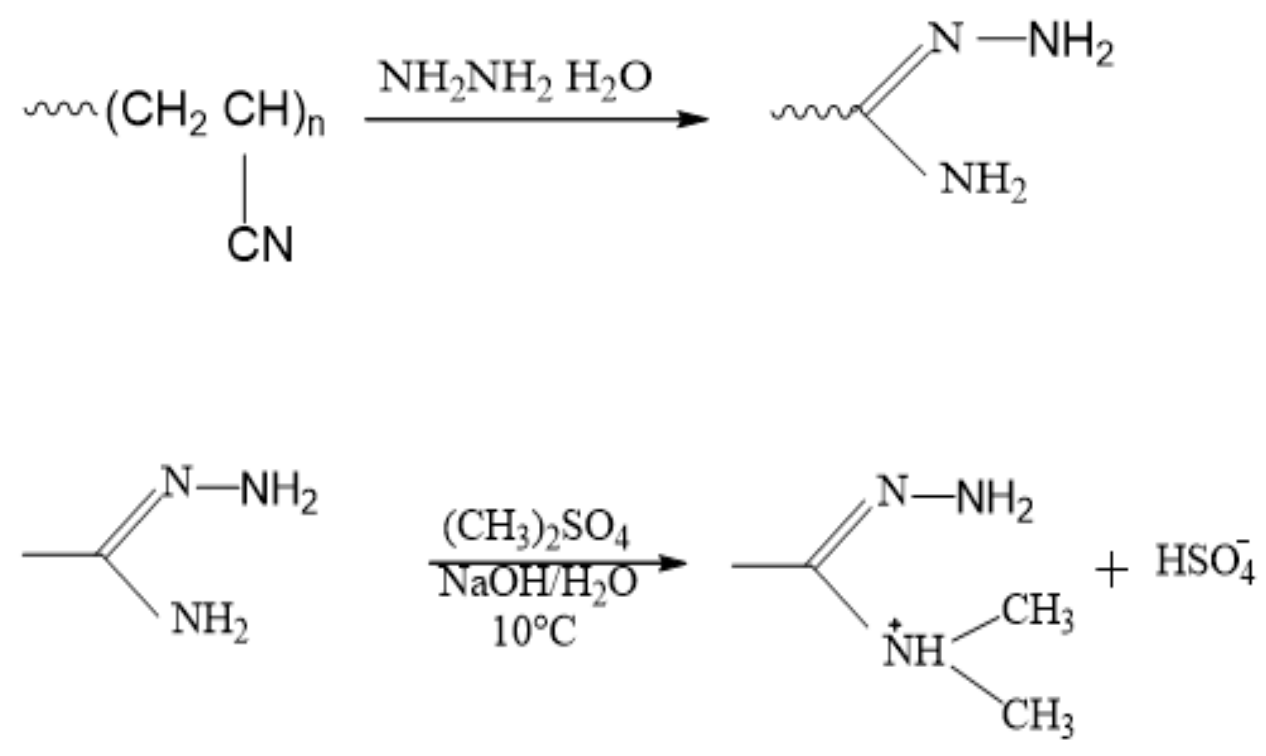

3.2. Combined effect of monomer concentration and irradiation dose on the extent of grafting (\%)

Figure 1 shows the relationship between the AN grafting percentage at different \% concentrations $\left(\mathrm{y}_{1}=10, \mathrm{y}_{2}=20, \mathrm{y}_{3}=30, \mathrm{y}_{4}=40\right.$ and $\left.\mathrm{y}_{5}=50 \%\right)$ and the different radiation doses applied during the graft reaction. As demonstrated in Figure 1, the grafting rate sustained a linear relationship with monomer concentration at the initial stage of the grafting reaction. This linear relationship subsequently levelled off at higher monomer concentrations. This variation in the grafting rate may be explained in terms of the non-radical grafting mechanism, where for this type of heterogeneous polymerization reaction represented in the study, the monomer is somehow distributed between the aqueous phase and the stationary cellulose interface. Meanwhile, the relative extent of such distribution is dependent on the polarity of the monomer molecules. It is also expected that a relatively high proportion of a polar monomer, such as acrylonitrile, will be in the aqueous phase and accordingly, a reduced amount of acrylonitrile molecules will be available at the cellulose interface (grafting site) and hence low grafting levels are expected [85]. 
Using the procedure of styrene comonomer [86], it was observed that the involvement of styrene as a component of the monomer mixture, enhanced the copolymerization of the second reactive monomer via mutual irradiation with a minimum formation of homopolymer. The utilization of such a technique leads to a remarkable reduction in the acrylonitrile key performance index $\left(\mathrm{K}_{\mathrm{p}}\right)$ in the presence of styrene. In other words, the presence of $0.05 \%(\mathrm{w} / \mathrm{v})$ of styrene in the monomer feed, results in the reduction of acrylonitrile homo-polymerization reaction and accordingly decreases its competition with the desired graft polymerization reaction.

Figure 1 also depicts the relationship between the graft rate variation with varying radiation doses (5KGy to $15 \mathrm{KGy}$ ). The plot shows an initial increase in the extent of grafting when the radiation doses increased up to $10 \mathrm{KGy}$. It was however observed that the grafting rate also tends to level off when the radiation dose increased beyond $10 \mathrm{KGy}$. The number of free radicals created by the radiation process initially increased linearly with increasing radiation dose. Meanwhile, at higher radiation doses (beyond $10 \mathrm{KGy}$ ), the number of free radicals decreased, due to the recombination of the formed radicals, useful for initiating the graft polymerization reaction [87] Also, at this levelling off point, the grafting reaction itself becomes a diffusion-controlled process [88].

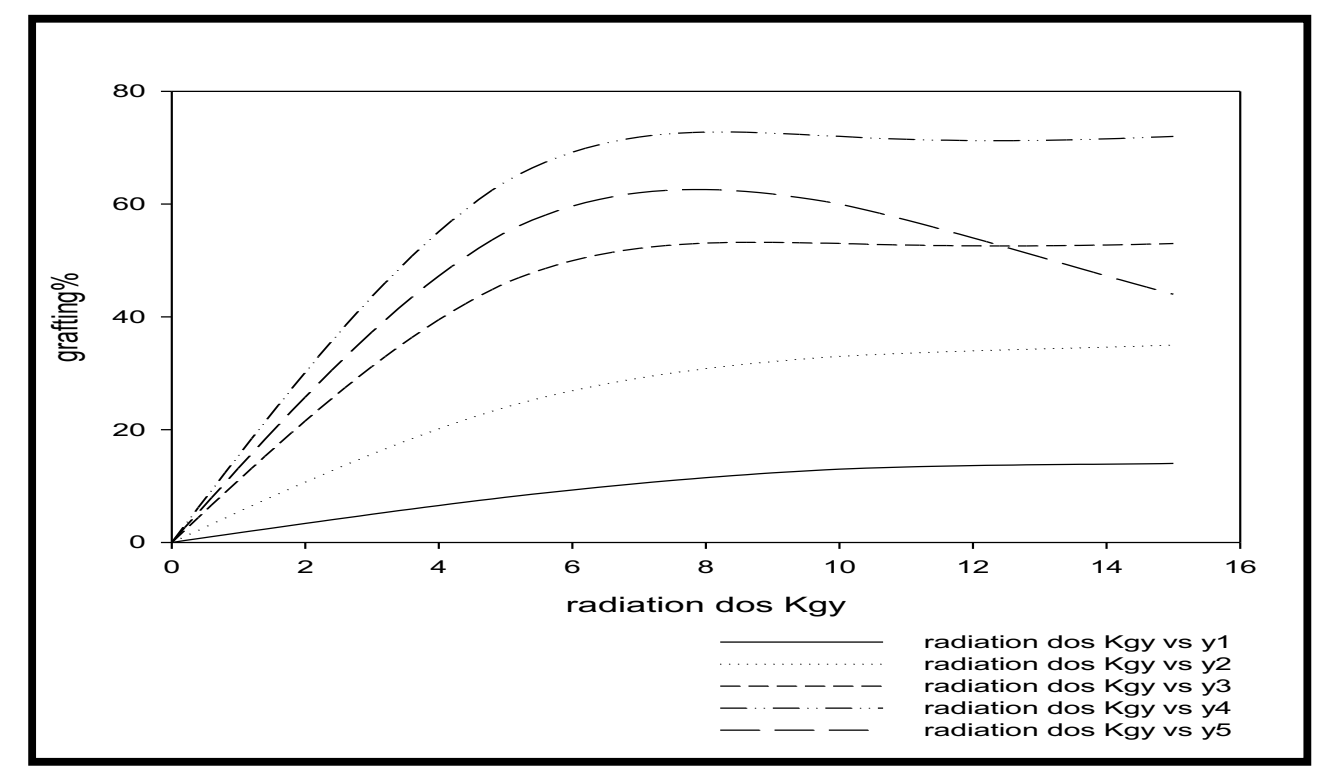

Figure 1: Relationship between grafting $\%$ and radiation dose at different monomer concentration. 


\subsection{Adsorbent characterization}

\subsubsection{FTIR analyses of the samples}

The IR spectra of the untreated cotton fabric, AN-g-cotton fabric, grafted cotton fabric modified with hydrazine hydrate, and modified graft finally alkylated with dimethyl sulfate were recorded and presented in Figure 2, to confirm the effectiveness of the successive modification reactions on the cotton fabric structure. The untreated cotton fabric showed certain signature peaks at $3500 \mathrm{~cm}^{-1}(\mathrm{OH}$ stretching), $2936 \mathrm{~cm}^{-1}$ (C-H stretching), and $1450 \mathrm{~cm}^{-1}$ (methyl C-H asym./sym. bend) [89, 90]. The IR analysis of the AN-g-cotton fabric showed the presence of a sharp peak at 3380, 2240 and 1652 $\mathrm{cm}^{-1}$ which are related to the $\mathrm{NH}$ stretch, aliphatic cyanide/nitrile group and imine groups, confirmation of the success of the acrylonitrile grafting. Furthermore, the successful modification of the grafted cotton fabric with the hydrazine hydrate led to the disappearance of the band corresponding to the nitrile group at $2240 \mathrm{~cm}^{-1}$ and the creation of a new amidrazone characteristics band due to $\mathrm{NH}_{2}$ and $\mathrm{NH}$ groups at $3470 \mathrm{~cm}^{-1}$ and $2934 \mathrm{~cm}^{-1}$. Another strong band at $1697 \mathrm{~cm}^{-1}$ and $1343 \mathrm{~cm}^{-1}$ corresponding to $\mathrm{C}=\mathrm{N}$ and $\mathrm{C}-\mathrm{N}$, respectively. The spectra of dimethyl sulfate $/ \mathrm{NaOH}$ alkylated fabric is characterized by the disappearance of the band at 1343 and $2934 \mathrm{~cm}^{-1}$ due to the interaction with dimethyl sulfate. Similarly, the strong band existing between 3000 to $3700 \mathrm{~cm}^{-1}$ is synonymous with the $\mathrm{OH}$ stretching vibration in carboxylates, thus verifying the formation of carboxylate cation-exchange groups.

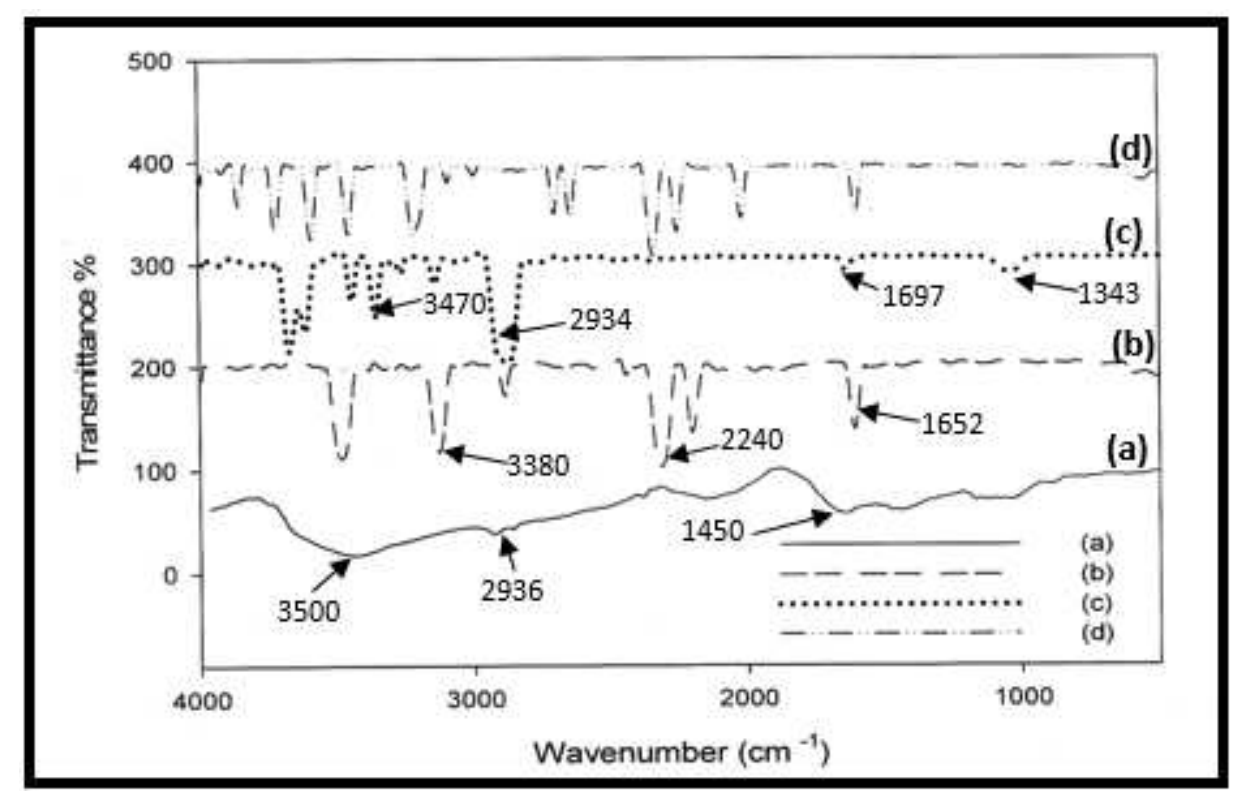

Figure 2: FTIR of cotton fabric (a) AN-g-cotton fabric (b), chemically treated g-fabric with hydrazine hydrate(c) and treated fabric with dimethyl sulfate (d). 


\subsubsection{SEM analyses of the samples}

Figure 3 shows the SEM graphs of untreated cotton fabric, AN-g-cotton fabric, grafted cotton fabric modified with hydrazine hydrate and modified graft finally alkylated with dimethyl sulfate. Figure 3a showed a fibrous structure composed of randomly-layered smooth fibres with high porosity. The morphology of cotton fabric grafted with $72 \%$ poly-AN (Figure 3b), differ significantly from that of the untreated cotton fabric, as the fibres become thicker in diameter and covered with rough layers of polyacrylonitrile. The entire fibre also appeared to be coated with polymer-deposits because of monomer penetration, diffusion and consequent grafting in between the fibres. Modification of the grafted cotton fabric with hydrazine hydrate, (Figure 3c) resulted in the change of both polymer-deposits and pore-size. The polymer deposits in the modified cotton fabric appeared to be soft and concentrated only on the surface of the fibre and not in between the fibres, that is why the hydrazine hydrate-modified cotton fabric possesses higher porosity, as compared with the AN-grafted cotton fabric. Also, the fibrous structure showed evidence of damage after modification with hydrazine hydrate as a result of fibre protection by a layer of graft polyacrylonitrile. Further modification with dimethyl sulfate shows that the pores of the fibres are almost enclosed with a complete collapse in the fibrous structure as shown in Figure 3d.

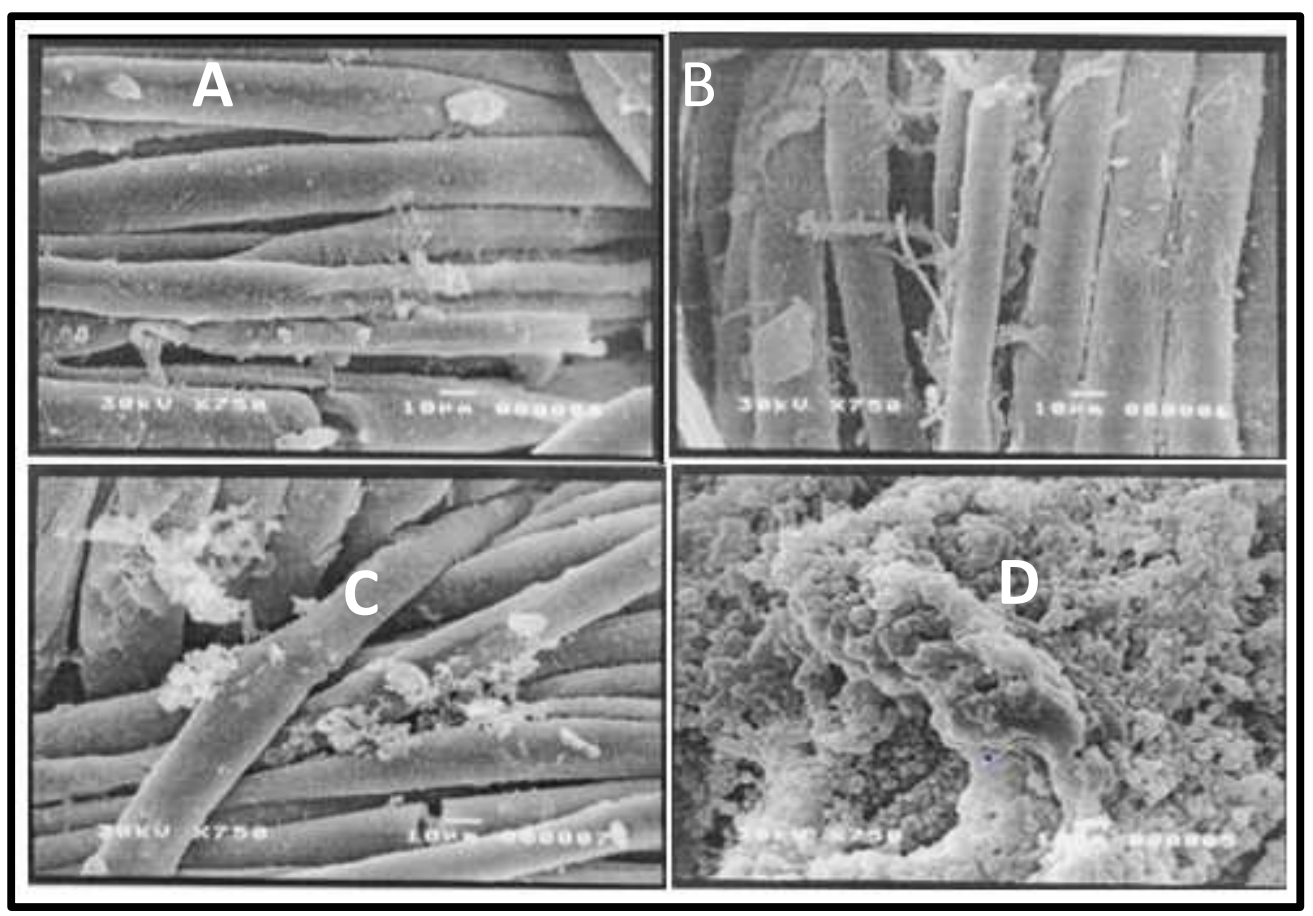

Figure 3: SEM images of (a) unmodified cellulose (b) grafted cellulose (c) hydrazine hydrate modified cellulose (d) dimethyl sulfate modified cellulose 


\subsection{Adsorption modelling}

\subsubsection{Isotherm studies}

Meanwhile, the effect of variation of adsorbate concentration on the equilibrium adsorption data was fitted to the isotherm models whose equations are depicted in Table 1, while the associated parametric and $\mathrm{R}^{2}$-values are presented in Tables $\mathbf{3}$ and $\mathbf{4}$ for nitrate and phosphate adsorption, respectively. The graphical illustration of the experimental dataset for nitrate and phosphate adsorption was plotted and presented in Figure 4 and 5, respectively. Generally, certain isotherm model parameters provide reasonable information on the nature of the adsorption system. For instance, when the Langmuir separation factor, $\left(\mathrm{R}_{\mathrm{L}}\right)$ is either greater than or equal to unity, the adsorption process is considered to be linear and unfavourable, respectively. Similarly, when the $\mathrm{R}_{\mathrm{L}}$ value is greater than zero but less than unity, a favourable adsorption system is implied, while, irreversible adsorption is signified by $\mathrm{R}_{\mathrm{L}}=0$. Furthermore, the Freundlich model indicates a linear, chemical and physical nature of an adsorption system when $\mathrm{n}_{\mathrm{F}}=1, \mathrm{n}_{\mathrm{F}}<1$ and $\mathrm{n}_{\mathrm{F}}>1$, respectively. Similarly, the $1 / \mathrm{n}_{\mathrm{F}}$-value is expected to be in the range of 0 and 1 , for feasible adsorption. The Temkins' adsorption energy variation constant, $\mathrm{b}_{\mathrm{T}}$ indicates an exothermic (when $\mathrm{b}_{\mathrm{T}}$-value is positive) and endothermic (when $\mathrm{b}_{\mathrm{T}}$-value is negative) process.

Based on the model parameters presented in Tables 3 and 4, the adsorption feasibility conditions were satisfactorily met in the study. The Langmuir model fit gave an $\mathrm{R}_{\mathrm{L}}$ value of 0.21 and $0.11\left(0<\mathrm{R}_{\mathrm{L}}<1\right)$, for nitrate and phosphate ions, respectively, thus, indicating favourable adsorption. The Freundlich heterogeneity constant, $\mathrm{n}_{\mathrm{F}}$ was found to be 2.577 and $2.054(0<\mathrm{n}<10)$, for nitrate and phosphate ions, respectively again indicating the favourability of this process. However, the inverse value $\left(1 / \mathrm{n}_{\mathrm{F}}\right)$ of the heterogeneity constant is lower than unity and as such suggests a slight suppression in respective anion adsorption at lower equilibrium concentrations. A positive value of $b_{T}$ constant depicted in Tables 3 and 4 for both anions indicates the exothermicity of the respective anion adsorption onto ' $C e l l-A E$ '. Consequently, the calculated D-R mean adsorption energy, E $(\mathrm{kJ} / \mathrm{mol})$ for both anions which are greater than $10 \mathrm{~kJ} / \mathrm{mol}$, favoured the occurrence of a chemical adsorption process.

Meanwhile, the insufficiency of the application $\mathrm{R}^{2}$-value alone for the determination of the best fit nonlinear model has been highlighted [2]. As a result, seven (7) error model, whose equations are presented in Table 2 were applied for determining the best-fit isotherm model. To limit the inconsistencies often experienced during the application of multiple error model (as was the case in this study), a process of normalizing the different error values from the error 
models for a given isotherm was adopted. Consequently, only the sum of normalized error (SNE) value will be considered during the isotherm modelling discussion and the lower the SNE value (as shown in Tables 5 and 6), the better the model fit to the experimental isotherm data.

The Redlich-Peterson (R-P) and Dubinin-Radushkevich (D-R) models, respectively emerged as the overall best fit for nitrate and phosphate ions, since both models returned the lowest SNE value (Tables 5 and 6), together with an appreciably high $\mathrm{R}^{2}$-value (Tables 3 and 4).

Table 3: Isotherm model parameters for the nitrate ion

\begin{tabular}{llll}
\hline \multicolumn{4}{c}{ 2-parameter models } \\
\hline Langmuir & Freundlich & Temkin & $\mathrm{D}^{*} \mathrm{R}^{*}$ \\
\hline $\mathrm{q}_{\max }=120.537$ & $\mathrm{n}_{\mathrm{F}}=2.577$ & $\mathrm{~A}_{\mathrm{T}}=62.604$ & $\mathrm{q}_{\mathrm{o}}=122.785$ \\
$\mathrm{~K}_{\mathrm{L}}=25.032$ & $1 / \mathrm{n}_{\mathrm{F}}=0.388$ & $\mathrm{~b}_{\mathrm{T}}=195.093$ & $\mathrm{~B}_{\mathrm{D}}=1.0 \mathrm{E}-04$ \\
$\mathrm{R}_{\mathrm{L}}=0.210$ & $\mathrm{~K}_{\mathrm{F}}=19.259$ & $\mathrm{R}^{2}=0.954$ & $\mathrm{E}=70.71$ \\
$\mathrm{R}^{2}=0.963$ & $\mathrm{R}^{2}=0.997$ & $\mathrm{R}^{2}=0.979$ \\
\hline \multicolumn{5}{c}{} & 3-parameter models \\
\hline Khan & $\mathrm{R}^{*} \mathrm{P}^{*}$ & Sips & Toth \\
\hline $\mathrm{q}_{\max }=2.298$ & $\mathrm{k}_{\mathrm{g}}=115.609$ & $\mathrm{~K}_{\mathrm{S}}=20.296$ & $\mathrm{k}_{\mathrm{T}}=18.560$ \\
$\mathrm{~b}_{\mathrm{K}}=181.448$ & $\alpha_{\mathrm{R}}=0.098$ & $\alpha_{\mathrm{S}}=8.3 \mathrm{E}-03$ & $\alpha_{\mathrm{T}}=9.0 \mathrm{E}-02$ \\
$\alpha_{\mathrm{K}}=0.600$ & $\mathrm{~g}=0.011$ & $\beta_{\mathrm{S}}=0.387$ & $1 / \mathrm{t}=0.604$ \\
$\mathrm{R}^{2}=0.997$ & $\mathrm{R}^{2}=0.987$ & $\mathrm{R}^{2}=0.997$ & $\mathrm{R}^{2}=0.997$ \\
\hline
\end{tabular}

*D-R = Dubinin-Radushkevich; R-P = Redlich-Peterson

Table 4: Isotherm model parameters for phosphate ion

\begin{tabular}{llll}
\hline \multicolumn{4}{c}{ 2-parameter models } \\
\hline Langmuir & Freundlich & Temkin & $\mathrm{D}-\mathrm{R}^{*}$ \\
\hline $\mathrm{q}_{\max }=260.00$ & $\mathrm{n}_{\mathrm{F}}=2.054$ & $\mathrm{~A}_{\mathrm{T}}=62.756$ & $\mathrm{q}_{\mathrm{o}}=262.494$ \\
$\mathrm{~K}_{\mathrm{L}}=26.00$ & $1 / \mathrm{n}_{\mathrm{F}}=0.487$ & $\mathrm{~b}_{\mathrm{T}}=97.725$ & $\mathrm{~B}_{\mathrm{D}}=4.9 \mathrm{E}-05$ \\
$\mathrm{R}_{\mathrm{L}}=0.111$ & $\mathrm{~K}_{\mathrm{F}}=29.083$ & $\mathrm{R}^{2}=0.948$ & $\mathrm{E}=101.01$ \\
$\mathrm{R}^{2}=0.984$ & $\mathrm{R}^{2}=0.999$ & $\mathrm{R}^{2}=0.979$ \\
\hline \multicolumn{5}{c}{} & & \\
\hline Khan & $\mathrm{R}-\mathrm{P}^{*}$ & Sips & Toth \\
\hline $\mathrm{q}_{\max }=2.303$ & $\mathrm{k}_{\mathrm{g}}=9.553$ & $\mathrm{~K}_{\mathrm{S}}=8.264$ & $\mathrm{k}_{\mathrm{T}}=28.845$ \\
$\mathrm{~b}_{\mathrm{K}}=183.337$ & $\alpha_{\mathrm{R}}=-0.834$ & $\alpha_{\mathrm{S}}=2.5 \mathrm{E}-02$ & $\alpha \mathrm{T}=8.7 \mathrm{E}-02$ \\
$\alpha_{\mathrm{K}}=0.513$ & $\mathrm{~g}=0.031$ & $\beta_{\mathrm{S}}=1.069$ & $1 / \mathrm{t}=0.511$ \\
$\mathrm{R}^{2}=0.999$ & $\mathrm{R}^{2}=0.995$ & $\mathrm{R}^{2}=0.998$ & $\mathrm{R}^{2}=0.999$ \\
\hline
\end{tabular}

*D-R = Dubinin-Radushkevich; R-P = Redlich-Peterson 
Table 5: Error-values for isotherm modelling of nitrate ion

\begin{tabular}{|c|c|c|c|}
\hline \multicolumn{4}{|c|}{ 2-parameter models } \\
\hline Langmuir & Freundlich & Temkin & D-R* \\
\hline $\mathrm{ARE}=2.684$ & $\mathrm{ARE}=0.701$ & $\mathrm{ARE}=3.208$ & $\mathrm{ARE}=1.698$ \\
\hline $\mathrm{APE}=33.557$ & $\mathrm{APE}=8.759$ & $\mathrm{APE}=40.099$ & $\mathrm{APE}=21.223$ \\
\hline $\mathrm{EABS}=125.289$ & $\mathrm{EABS}=31.660$ & $\mathrm{EABS}=123.409$ & $\mathrm{EABS}=70.901$ \\
\hline$E R R S Q=3360.481$ & $E R R S Q=216.416$ & ERRSQ $=3975.647$ & $\mathrm{ERRSQ}=1747.958$ \\
\hline Hybrid $=81.918$ & Hybrid $=6.364$ & Hybrid $=133.446$ & Hybrid $=42.494$ \\
\hline MPSD $=2.711$ & MPSD $=0.258$ & MPSD $=5.377$ & MPSD $=1.337$ \\
\hline$X^{2}=42.094$ & $X^{2}=4.553$ & $X^{2}=50.207$ & $X^{2}=23.456$ \\
\hline $\mathrm{SNE}=1.086$ & $\mathrm{SNE}=1.241$ & $\mathrm{SNE}=\mathbf{1 . 0 8 9}$ & $\mathrm{SNE}=1.092$ \\
\hline \multicolumn{4}{|c|}{ 3-parameter models } \\
\hline Khan & R-P* & Sips & Toth \\
\hline $\mathrm{ARE}=0.653$ & $\mathrm{ARE}=5.340$ & $\mathrm{ARE}=0.744$ & $\mathrm{ARE}=0.647$ \\
\hline $\mathrm{APE}=8.161$ & $\mathrm{APE}=66.750$ & $\mathrm{APE}=9.297$ & $\mathrm{APE}=8.081$ \\
\hline $\mathrm{EABS}=31.736$ & $\mathrm{EABS}=200.832$ & $\mathrm{EABS}=30.527$ & $\mathrm{EABS}=31.331$ \\
\hline $\mathrm{ERRSQ}=208.350$ & ERRSQ $=10730.17$ & $E R R S Q=226.390$ & ERRSQ $=202.685$ \\
\hline Hybrid $=5.396$ & Hybrid $=378.521$ & Hybrid $=7.555$ & Hybrid $=5.277$ \\
\hline MPSD $=0.208$ & MPSD $=15.634$ & MPSD $=0.317$ & MPSD $=0.204$ \\
\hline$X^{2}=4.067$ & $X^{2}=99.872$ & $X^{2}=5.130$ & $X^{2}=3.981$ \\
\hline $\mathrm{SNE}=1.241$ & $\mathrm{SNE}=1.071$ & $\mathrm{SNE}=1.237$ & $\mathrm{SNE}=1.244$ \\
\hline
\end{tabular}

*D-R = Dubinin-Radushkevich; R-P = Redlich-Peterson

Table 6: Error-values for isotherm modelling of phosphate ion

\begin{tabular}{|c|c|c|c|}
\hline \multicolumn{4}{|c|}{ 2-parameter models } \\
\hline Langmuir & Freundlich & Temkin & D-R* \\
\hline ARE $=0.998$ & $\mathrm{ARE}=0.112$ & $\mathrm{ARE}=2.082$ & $\mathrm{ARE}=1.380$ \\
\hline $\mathrm{APE}=16.630$ & $\mathrm{APE}=1.871$ & $\mathrm{APE}=34.700$ & $\mathrm{APE}=23.00$ \\
\hline $\mathrm{EABS}=119.389$ & $\mathrm{EABS}=19.422$ & $\mathrm{EABS}=198.027$ & $\mathrm{EABS}=140.99$ \\
\hline ERRSQ $=3639.54$ & ERRSQ $=183.824$ & ERRSQ $=11850.77$ & $E R R S Q=5821.17$ \\
\hline Hybrid $=31.565$ & Hybrid $=0.977$ & Hybrid $=149.791$ & Hybrid $=71.975$ \\
\hline MPSD $=0.317$ & $\mathrm{MPSD}=5.3 \mathrm{E}-03$ & MPSD $=2.121$ & $\mathrm{MPSD}=1.047$ \\
\hline$X^{2}=23.553$ & $\mathrm{X}^{2}=1.0380$ & $\mathrm{X}^{2}=73.240$ & $X^{2}=469767.6$ \\
\hline $\mathrm{SNE}=\mathbf{1 . 0 5 3}$ & $\mathrm{SNE}=1.127$ & $\mathrm{SNE}=1.039$ & $\mathrm{SNE}=\mathbf{1 . 0 1 3}$ \\
\hline \multicolumn{4}{|c|}{ 3-parameter models } \\
\hline Khan & R-P* & Sips & Toth \\
\hline $\mathrm{ARE}=0.111$ & $\mathrm{ARE}=0.500$ & $\mathrm{ARE}=0.398$ & $\mathrm{ARE}=0.105$ \\
\hline $\mathrm{APE}=1.865$ & $\mathrm{APE}=8.331$ & $\mathrm{APE}=6.638$ & $\mathrm{APE}=1.752$ \\
\hline $\mathrm{EABS}=19.396$ & $\mathrm{EABS}=57.836$ & $\mathrm{EABS}=31.897$ & $\mathrm{EABS}=19.592$ \\
\hline$E R R S Q=183.683$ & ERRSQ $=951.168$ & $\mathrm{ERRSQ}=525.615$ & $E R R S Q=191.636$ \\
\hline Hybrid $=0.976$ & Hybrid $=8.946$ & Hybrid $=7.951$ & Hybrid $=1.005$ \\
\hline $\mathrm{MPSD}=5.3 \mathrm{E}-03$ & MPSD $=0.111$ & MPSD $=0.125$ & $\mathrm{MPSD}=5.2 \mathrm{E}-03$ \\
\hline$X^{2}=1.036$ & $X^{2}=7.798$ & $X^{2}=12.197$ & $X^{2}=1.071$ \\
\hline $\mathrm{SNE}=\mathbf{1 . 1 2 7}$ & $\mathrm{SNE}=\mathbf{1 . 0 8 8}$ & $\mathrm{SNE}=1.113$ & $\mathrm{SNE}=1.123$ \\
\hline
\end{tabular}

*D-R = Dubinin-Radushkevich; R-P = Redlich-Peterson 

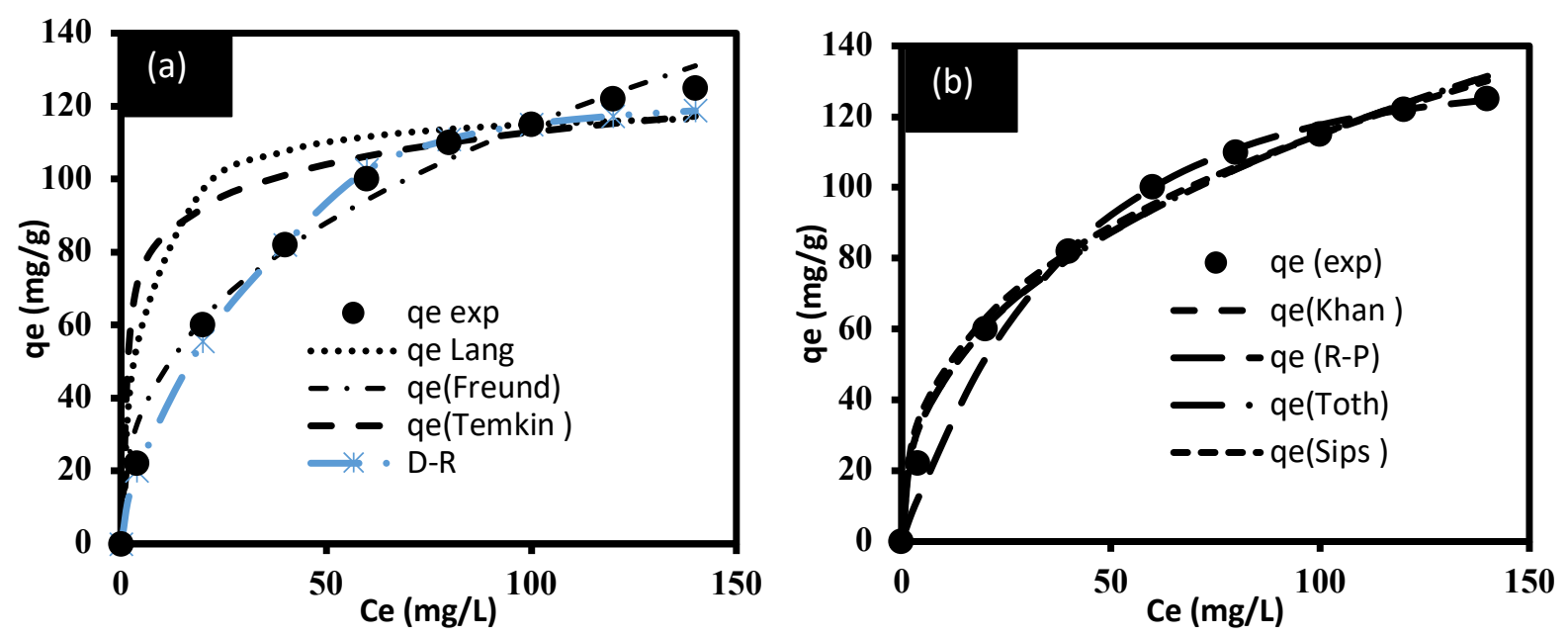

Figure 4: (a) 2-parameter and (b) 3-parameter isotherm plots for nitrate adsorption
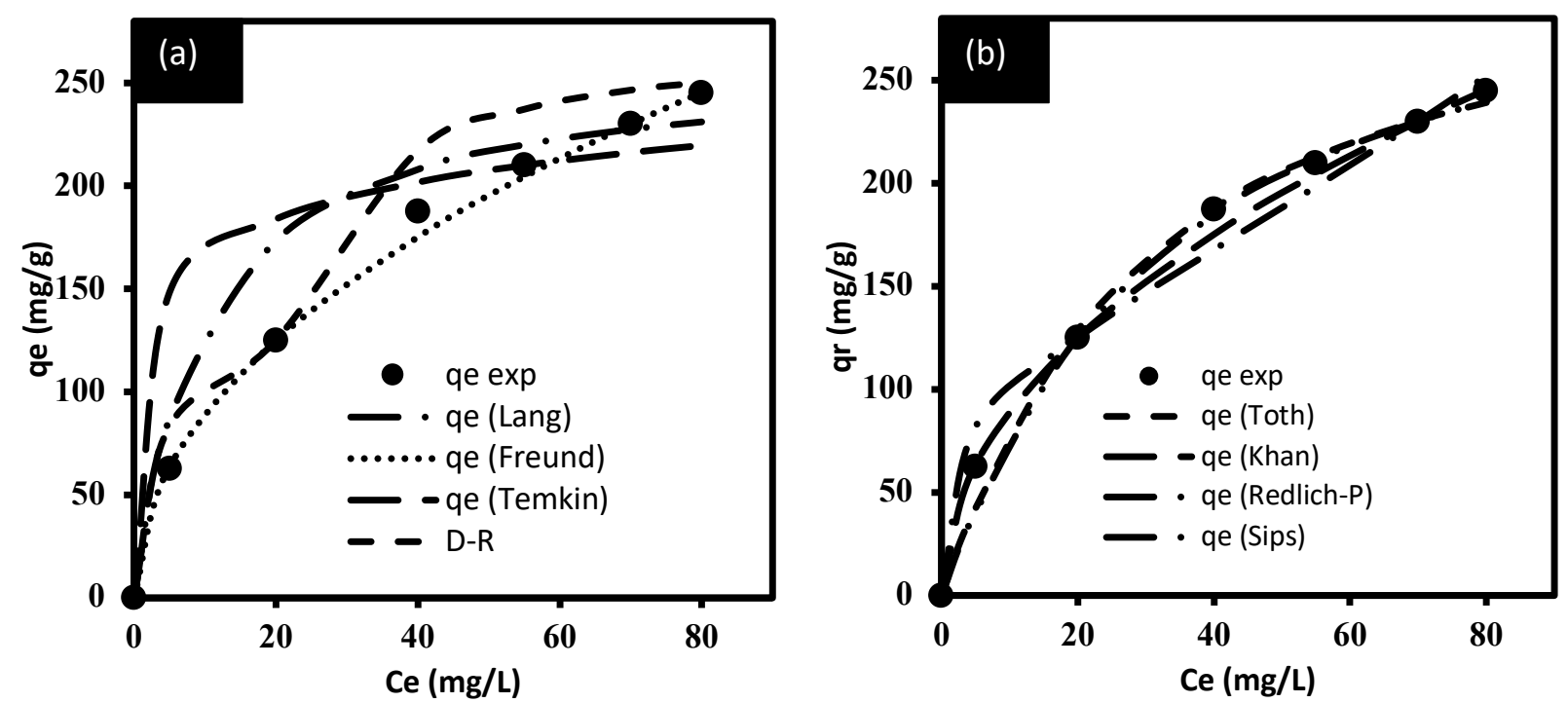

Figure 5: (a) 2-parameter and (b) 3-parameter isotherm plots for phosphate adsorption

\section{Conclusion}

- $\quad C e l l-A E$ ' adsorbent, with abundant amine functional groups was synthesized via the graft copolymerization of acrylonitrile and cotton fabric waste. The graft product was subsequently functionalized with hydrazine hydrate and alkalified dimethyl sulfate.

- FTIR spectroscopy and SEM instrumental characterization studies elucidated the available functional groups on the adsorbent, as well as their surface morphologies.

- $\quad$ Based on the equilibrium studies, R-P and D-R models provided the best fitting to the nitrate and phosphate adsorption experimental data.

- The successful application of the 'Cell-AE' adsorbent synthesized from waste cotton fabric for the uptake of $\mathrm{NO}_{3}{ }^{-}$and $\mathrm{PO}_{4}{ }^{3-}$ ions provides a combined advantage of 
decreasing the volume of existing solid wastes and simultaneously producing a valuable adsorbent at a lower cost.

\section{Conflict of interest declaration}

The authors declare that they have no known competing interest regarding the work reported in this manuscript.

\section{References}

1. Oke, S.A. and F. Fourie, Guidelines to groundwater vulnerability mapping for SubSaharan Africa. Groundwater for Sustainable Development, 2017. 5: p. 168-177.

2. Abonyi, M., C. Aniagor, and M. Menkiti, Effective Dephenolation of Effluent from Petroleum Industry Using Ionic-Liquid-Induced Hybrid Adsorbent. Arabian Journal for Science and Engineering, 2019. 44(12): p. 10017-10029.

3. Huang, K., J. Liang, J. Wang, Y. Ouyang, R. Wang, T. Tang, Y. Luo, X. Tao, H. Yin, Z. Dang, and G. Lu, Effect of nitrate on the phototreatment of Triton X-100 simulated washing waste containing 4,4'-dibromodiphenyl ether: Kinetics, products and toxicity assessment. Science of The Total Environment, 2020. 732: p. 139247.

4. Banu, H.A.T., P. Karthikeyan, and S. Meenakshi, Synthesis and characterization of Ce(III) decorated Duolite resin and its removal performance of toxic anions from aqueous solutions. Environmental Chemistry and Ecotoxicology, 2021. 3: p. 8-16.

5. Yin, Q., H. Ren, R. Wang, and Z. Zhao, Evaluation of nitrate and phosphate adsorption on Al-modified biochar: Influence of Al content. Science of the Total Environment, 2018. 631: p. 895-903.

6. Berkessa, Y.W., S.T. Mereta, and F.F. Feyisa, Simultaneous removal of nitrate and phosphate from wastewater using solid waste from factory. Applied Water Science, 2019. 9(2): p. 1-10.

7. Reid, A.J., A.K. Carlson, I.F. Creed, E.J. Eliason, P.A. Gell, P.T. Johnson, K.A. Kidd, T.J. MacCormack, J.D. Olden, and S.J. Ormerod, Emerging threats and persistent conservation challenges for freshwater biodiversity. Biological Reviews, 2019. 94(3): p. 849-873.

8. Rajeswari, M., R. Seenivasagan, P. Prabhakaran, S. Rajakumar, and P.M. Ayyasamy, Lab scale process on the removal of nitrate in ground water enriched with denitrifying bacterium and starch as a sole carbon source. Journal of Water Process Engineering, 2016. 13: p. 189-195. 
9. Marcus, N., An overview of the impacts of eutrophication and chemical pollutants on copepods of the coastal zone. Zoological studies, 2004. 43(2): p. 211-217.

10. Mahmud, M.A.P., F. Ejeian, S. Azadi, M. Myers, B. Pejcic, R. Abbassi, A. Razmjou, and M. Asadnia, Recent progress in sensing nitrate, nitrite, phosphate, and ammonium in aquatic environment. Chemosphere, 2020. 259: p. 127492.

11. Xiang, Q.-Q., Y. Gao, Q.-Q. Li, J. Ling, and L.-Q. Chen, Proteomic profiling reveals the differential toxic responses of gills of common carp exposed to nanosilver and silver nitrate. Journal of Hazardous Materials, 2020. 394: p. 122562.

12. Gupta, P. and C.S. Seth, Nitrate supplementation attenuates As(V) toxicity in Solanum lycopersicum L. cv Pusa Rohini: Insights into As(V) sub-cellular distribution, photosynthesis, nitrogen assimilation, and DNA damage. Plant Physiology and Biochemistry, 2019. 139: p. 44-55.

13. Edition, F., Guidelines for drinking-water quality. WHO chronicle, 2011. 38(4): p. 104108.

14. Huang, H., J. Liu, P. Zhang, D. Zhang, and F. Gao, Investigation on the simultaneous removal of fluoride, ammonia nitrogen and phosphate from semiconductor wastewater using chemical precipitation. Chemical Engineering Journal, 2017. 307: p. 696-706.

15. Kumar, T.P., T.R. Mandlimath, P. Sangeetha, S. Revathi, and S.A. Kumar, Nanoscale materials as sorbents for nitrate and phosphate removal from water. Environmental Chemistry Letters, 2018. 16(2): p. 389-400.

16. Yousefi, N., A. Fatehizedeh, K. Ghadiri, N. Mirzaei, S.D. Ashrafi, and A.H. Mahvi, Application of nanofilter in removal of phosphate, fluoride and nitrite from groundwater. Desalination and Water Treatment, 2016. 57(25): p. 11782-11788.

17. Chiu, S.-Y., C.-Y. Kao, T.-Y. Chen, Y.-B. Chang, C.-M. Kuo, and C.-S. Lin, Cultivation of microalgal Chlorella for biomass and lipid production using wastewater as nutrient resource. Bioresource technology, 2015. 184: p. 179-189.

18. Guedes, P., E.P. Mateus, J. Almeida, A.R. Ferreira, N. Couto, and A.B. Ribeiro, Electrodialytic treatment of sewage sludge: current intensity influence on phosphorus recovery and organic contaminants removal. Chemical Engineering Journal, 2016. 306: p. 1058-1066.

19. Zhao, Y., J. Wang, Z. Luan, X. Peng, Z. Liang, and L. Shi, Removal of phosphate from aqueous solution by red mud using a factorial design. Journal of Hazardous Materials, 2009. 165(1-3): p. 1193-1199. 
20. Hashem, A., A. Al-Anwar, N.M. Nagy, D.M. Hussein, and S. Eisa, Isotherms and kinetic studies on adsorption of Hg (II) ions onto Ziziphus spina-christi L. from aqueous solutions. Green Processing and Synthesis, 2016. 5(2): p. 213-224.

21. Hashem, A., A. Abou-Okeil, M. Fikry, A. Aly, and C.O. Aniagor, Isotherm and Kinetics Parametric Studies for Aqueous $\mathrm{Hg}(\mathrm{II}) \quad$ Uptake onto N-[2(Methylamino)Ethyl]Ethane-1,2-Diaminated Acrylic Fibre. Arabian Journal for Science and Engineering, 2021. https://doi.org/10.1007/s13369-021-05416-X.

22. Zeng, L., X. Li, and J. Liu, Adsorptive removal of phosphate from aqueous solutions using iron oxide tailings. Water research, 2004. 38(5): p. 1318-1326.

23. Hashem, A., C. Aniagor, D. Hussein, and S. Farag, Application of novel butane-1, 4dioic acid-functionalized cellulosic biosorbent for aqueous cobalt ion sequestration. Cellulose, 2021: p. 1-17.

24. Kumar, M., S. RaoT, A.M. Isloor, G.P.S. Ibrahim, Inamuddin, N. Ismail, A.F. Ismail, and A.M. Asiri, Use of cellulose acetate/polyphenylsulfone derivatives to fabricate ultrafiltration hollow fiber membranes for the removal of arsenic from drinking water. International Journal of Biological Macromolecules, 2019. 129: p. 715-727.

25. Teodoro, F.S., M.M.C. Elias, G.M.D. Ferreira, O.F.H. Adarme, R.M.L. Savedra, M.F. Siqueira, L.H.M. da Silva, L.F. Gil, and L.V.A. Gurgel, Synthesis and application of a new carboxylated cellulose derivative. Part III: Removal of auramine-O and safraninT from mono- and bi-component spiked aqueous solutions. Journal of Colloid and Interface Science, 2018. 512: p. 575-590.

26. Teodoro, F.S., S.N.d.C. Ramos, M.M.C. Elias, A.B. Mageste, G.M.D. Ferreira, L.H.M. da Silva, L.F. Gil, and L.V.A. Gurgel, Synthesis and application of a new carboxylated cellulose derivative. Part I: Removal of $\mathrm{Co} 2+, \mathrm{Cu} 2+$ and $\mathrm{Ni} 2+$ from monocomponent spiked aqueous solution. Journal of Colloid and Interface Science, 2016. 483: p. 185200.

27. Xu, X., J. Yu, C. Liu, G. Yang, L. Shi, and X. Zhuang, Xanthated chitosan/cellulose sponges for the efficient removal of anionic and cationic dyes. Reactive and Functional Polymers, 2021. 160: p. 104840.

28. Zhuang, S., K. Zhu, and J. Wang, Fibrous chitosan/cellulose composite as an efficient adsorbent for Co( II) removal. Journal of Cleaner Production, 2021. 285: p. 124911. 
29. Hashem, A., H. Sokker, E.A. Halim, and A. Gamal, $\gamma$-induced graft copolymerization onto cellulosic fabric waste for cationic dye removal. Adsorption Science \& Technology, 2005. 23(6): p. 455-466.

30. Sokker, H., E.A. Halim, A. Aly, and A. Hashem, Cellulosic fabric wastes grafted with DMAEMA for the removal of direct dyes. Adsorption Science \& Technology, 2004. 22(9): p. 679-691.

31. Aly, A., H. Sokker, A. Hashem, and A. Hebeish, Preparation of cellulosic membrane containing pyrrolidone moiety via radiation induced grafting and its application in wastewater treatment. 2005.

32. Badawy, S.M., H.H. Sokker, S.H. Othman, and A. Hashem, Cloth filter for recovery of uranium from radioactive waste. Radiation Physics and Chemistry, 2005. 73(2): p. 125130.

33. Abousalman-Rezvani, Z., P. Eskandari, H. Roghani-Mamaqani, H. Mardani, and M. Salami-Kalajahi, Grafting light-, temperature, and CO2-responsive copolymers from cellulose nanocrystals by atom transfer radical polymerization for adsorption of nitrate ions. Polymer, 2019. 182: p. 121830.

34. Eskandari, P., Z. Abousalman-Rezvani, H. Roghani-Mamaqani, and M. SalamiKalajahi, Carbon dioxide-switched removal of nitrate ions from water by cellulose nanocrystal-grafted and free multi-responsive block copolymers. Journal of Molecular Liquids, 2020. 318: p. 114301.

35. Xu, C., J. Jiang, H. Oguzlu, Y. Zheng, and F. Jiang, Antifouling, antibacterial and noncytotoxic transparent cellulose membrane with grafted zwitterion and quaternary ammonium copolymers. Carbohydrate Polymers, 2020. 250: p. 116960.

36. Li, Y., D. Xie, J. Xiao, W. Wu, L. Zhang, H. Xiao, and J. Chen, Dual responsive copolymers-grafted microfibrillated cellulose composites for removing lead ions from aqueous solution. Journal of Cleaner Production, 2020. 258: p. 120867.

37. Eskandari, P., H. Roghani-Mamaqani, M. Salami-Kalajahi, and Z. AbousalmanRezvani, Modification of cellulose nanocrystal with dual temperature- and CO2responsive block copolymers for ion adsorption applications. Journal of Molecular Liquids, 2020. 310: p. 113234.

38. Kumar, R., R.K. Sharma, and A.P. Singh, Removal of organic dyes and metal ions by cross-linked graft copolymers of cellulose obtained from the agricultural residue. Journal of Environmental Chemical Engineering, 2018. 6(5): p. 6037-6048. 
39. Hashem, A., S. Badawy, S. Farag, L. Mohamed, A. Fletcher, and G. Taha, Non-linear adsorption characteristics of modified pine wood sawdust optimised for adsorption of Cd (II) from aqueous systems. Journal of Environmental Chemical Engineering, 2020. 8(4): p. 103966.

40. Hashem, A., A. Fletcher, H. Younis, H. Mauof, and A. Abou-Okeil, Adsorption of Pb (II) ions from contaminated water by 1, 2, 3, 4-butanetetracarboxylic acid-modified microcrystalline cellulose: Isotherms, kinetics, and thermodynamic studies. International Journal of Biological Macromolecules, 2020. 164: p. 3193-3203.

41. Hashem, A., M. Sanousy, L.A. Mohamed, P.U. Okoye, and B. Hameed, Natural and Low-Cost P. turgidum for Efficient Adsorption of $\mathrm{Hg}$ (II) Ions from Contaminated Solution: Isotherms and Kinetics Studies. Journal of Polymers and the Environment, 2020: p. 1-9.

42. Hashem, A., H.A. Hammad, and A. Al-Anwar, Chemically modified Retama raetam biomass as a new adsorbent for Pb (II) ions from aqueous solution: non-linear regression, kinetics and thermodynamics. Green Processing and Synthesis, 2015. 4(6): p. 463-478.

43. Farag, A.M., H.H. Sokker, E.M. Zayed, F.A.N. Eldien, and N.M. Abd Alrahman, Removal of hazardous pollutants using bifunctional hydrogel obtained from modified starch by grafting copolymerization. International Journal of Biological Macromolecules, 2018. 120: p. 2188-2199.

44. Sokker, H., N.M. El-Sawy, M. Hassan, and B.E. El-Anadouli, Adsorption of crude oil from aqueous solution by hydrogel of chitosan based polyacrylamide prepared by radiation induced graft polymerization. Journal of Hazardous Materials, 2011. 190(13): p. 359-365.

45. Kumar, R., R.K. Sharma, and A.P. Singh, Grafting of cellulose with Nisopropylacrylamide and glycidyl methacrylate for efficient removal of $\mathrm{Ni}$ (II), Cu (II) and Pd (II) ions from aqueous solution. Separation and Purification Technology, 2019. 219: p. 249-259.

46. Mohamed, M.F., X. Zhou, H.S. Ibrahim, N.S. Ammar, and H.A. Essawy, Grafting polymerization of acrylic acid onto chitosan-cellulose hybrid and application of the graft as highly efficient ligand for elimination of water hardness: Validation of high selectivity in presence of interfering ions. International Journal of Biological Macromolecules, 2018. 116: p. 530-536. 
47. Liang, X., B. Liang, J. Wei, S. Zhong, R. Zhang, Y. Yin, Y. Zhang, H. Hu, and Z. Huang, A cellulose-based adsorbent with pendant groups of quaternary ammonium and amino for enhanced capture of aqueous Cr (VI). International Journal of Biological Macromolecules, 2020. 148: p. 802-810.

48. Dhakshinamoorthy, A., M. Alvaro, and H. Garcia, Metal organic frameworks as heterogeneous catalysts for the selective $N$-methylation of aromatic primary amines with dimethyl carbonate. Applied Catalysis A: General, 2010. 378(1): p. 19-25.

49. Lawley, P., D. Orr, and S. Shah, Reaction of alkylating mutagens and carcinogens with nucleic acids: N-3 of guanine as a site of alkylation by N-methyl-N-nitrosourea and dimethyl sulphate. Chemico-Biological Interactions, 1972. 4(6): p. 431-434.

50. Dominguez, L., J. Economy, K. Benak, and C.L. Mangun, Anion exchange fibers for arsenate removal derived from a vinylbenzyl chloride precursor. Polymers for Advanced Technologies, 2003. 14(9): p. 632-637.

51. Awual, M.R., M. Shenashen, T. Yaita, H. Shiwaku, and A. Jyo, Efficient arsenic (V) removal from water by ligand exchange fibrous adsorbent. water research, 2012. 46(17): p. 5541-5550.

52. Chaudhary, B.K. and J. Farrell, Preparation and characterization of homopolymer polyacrylonitrile-based fibrous sorbents for arsenic removal. Environmental engineering science, 2014. 31(11): p. 593-601.

53. Wang, J., X. Li, J.S. Ince, Z. Yue, and J. Economy, Iron oxide-coated on glass fibers for arsenic removal. Separation Science and Technology, 2010. 45(8): p. 1058-1065.

54. Economy, J., L. Dominguez, and C.L. Mangun, Polymeric ion-exchange fibers. Industrial \& engineering chemistry research, 2002. 41(25): p. 6436-6442.

55. Vatutsina, O., V. Soldatov, V. Sokolova, J. Johann, M. Bissen, and A. Weissenbacher, A new hybrid (polymer/inorganic) fibrous sorbent for arsenic removal from drinking water. Reactive and Functional Polymers, 2007. 67(3): p. 184-201.

56. Lin, J.-C. and A.K. SenGupta, Hybrid anion exchange fibers with dual binding sites: Simultaneous and reversible sorption of perchlorate and arsenate. Environmental engineering science, 2009. 26(11): p. 1673-1683.

57. Sha, B., J. Wang, L. Zhou, X. Zhang, L. Han, and L. Zhao, Adsorption of organic amines from wastewater by carboxyl group-modified polyacrylonitrile fibers. Journal of applied polymer science, 2013. 128(6): p. 4124-4129. 
58. Zhang, G., H. Meng, and S. Ji, Hydrolysis differences of polyacrylonitrile support membrane and its influences on polyacrylonitrile-based membrane performance. Desalination, 2009. 242(1-3): p. 313-324.

59. Yan, S., M. Zhao, G. Lei, and Y. Wei, Novel tetrazole-functionalized absorbent from polyacrylonitrile fiber for heavy-metal ion adsorption. Journal of applied polymer science, 2012. 125(1): p. 382-389.

60. Vargas, A.M., A.L. Cazetta, A.C. Martins, J.C. Moraes, E.E. Garcia, G.F. Gauze, W.F. Costa, and V.C. Almeida, Kinetic and equilibrium studies: Adsorption offood dyes Acid Yellow 6, Acid Yellow 23, and Acid Red 18 on activated carbon from flamboyant pods. Chemical engineering journal, 2012. 181: p. 243-250.

61. Menkiti, M., M. Abonyi, and C. Aniagor, Process Equilibrium, Kinetics, and Mechanisms of Ionic-Liquid Induced Dephenolation of Petroleum Effluent. Water Conservation Science and Engineering, 2018. 3(3): p. 205-220.

62. Langmuir, I., The constitution and fundamental properties of solids and liquids. Part I. Solids. Journal of the American chemical society, 1916. 38(11): p. 2221-2295.

63. Hashem, A., S. Badawy, S. Farag, L. Mohamed, A. Fletcher, and G. Taha, Non-linear adsorption characteristics of modified pine wood sawdust optimised for adsorption of Cd (II) from aqueous systems. Journal of Environmental Chemical Engineering, 2020: p. 103966.

64. Freundlich, H., Über die adsorption in lösungen. Zeitschrift für physikalische Chemie, 1907. 57(1): p. 385-470.

65. Ighalo, J.O., I.O. Tijani, J. Ajala, F.O. Ayandele, O. Eletta, and A.G. Adeniyi, Competitive Biosorption of $\mathrm{Pb}$ (II) and $\mathrm{Cu}$ (II) by Functionalised Micropogonias undulates Scales. Recent Innovations in Chemical Engineering, 2020. 13: p. 1-12.

66. Igwegbe, C.A., O.D. Onukwuli, J.O. Ighalo, and P.U. Okoye, Adsorption of cationic dyes on Dacryodes edulis seeds activated carbon modified using phosphoric acid and sodium chloride. Environmental Processes, 2020. 7(4): p. 1151-1171.

67. Menkiti, M., C. Aniagor, C. Agu, and V. Ugonabo, Effective adsorption of crystal violet dye from an aqueous solution using lignin-rich isolate from elephant grass. Water Conservation Science and Engineering, 2018. 3(1): p. 33-46.

68. Temkin, M., Kinetics of ammonia synthesis on promoted iron catalysts. Acta physiochim. URSS, 1940. 12: p. 327-356.

69. Foo, K.Y. and B.H. Hameed, Insights into the modeling of adsorption isotherm systems. Chemical engineering journal, 2010. 156(1): p. 2-10. 
70. Hashem, A., M. Nasr, A. Fletcher, and L.A. Mohamed, Aminated acrylic fabric waste derived sorbent for Cd (II) ion removal from aqueous solutions: mechanism, equilibria and kinetics. Journal of Polymers and the Environment, 2020: p. 1-12.

71. Khan, A., R. Ataullah, and A. Al-Haddad, Equilibrium adsorption studies of some aromatic pollutants from dilute aqueous solutions on activated carbon at different temperatures. Journal of colloid and interface science, 1997. 194(1): p. 154-165.

72. ANIAGOR, C.O. and M.C. MENKITI, RELATIONAL DESCRIPTION OF AN ADSORPTION SYSTEM BASED ON ISOTHERM, ADSORPTION DENSITY, ADSORPTION POTENTIAL, HOPPING NUMBER AND SURFACE COVERAGE. Sigma, 2020. 38(3): p. 1073-1098.

73. Redlich, O. and D.L. Peterson, A useful adsorption isotherm. Journal of physical chemistry, 1959. 63(6): p. 1024-1024.

74. Menkiti, M. and C. Aniagor, Parametric studies on descriptive isotherms for the uptake of crystal violet dye from aqueous solution onto lignin-rich adsorbent. Arabian Journal for Science and Engineering, 2018. 43(5): p. 2375-2392.

75. Toth, J., State equation of the solid-gas interface layers. Acta chim. hung., 1971. 69: p. 311-328.

76. Schweitzer, L. and J. Noblet, Water Contamination and Pollution. 2018. 10.1016/b9780-12-809270-5.00011-x: p. 261-290.

77. Yan, Y., X. Xu, C. Shi, W. Yan, L. Zhang, and G. Wang, Ecotoxicological effects and accumulation of ciprofloxacin in Eichhornia crassipes under hydroponic conditions. Environ Sci Pollut Res Int, 2019. 26(29): p. 30348-30355.

78. Marquardt, D.W., An algorithm for least-squares estimation of nonlinear parameters. Journal of the society for Industrial and Applied Mathematics, 1963. 11(2): p. 431-441.

79. Khair, U., H. Fahmi, S. Al Hakim, and R. Rahim. Forecasting error calculation with mean absolute deviation and mean absolute percentage error. in Journal of Physics: Conference Series. 2017. IOP Publishing.

80. Ng, J., W. Cheung, and G. McKay, Equilibrium studies of the sorption of Cu (II) ions onto chitosan. Journal of Colloid and Interface Science, 2002. 255(1): p. 64-74.

81. Kapoor, A. and R. Yang, Correlation of equilibrium adsorption data of condensible vapours on porous adsorbents. Gas Separation \& Purification, 1989. 3(4): p. 187-192.

82. Rivas, F., F. Beltrán, O. Gimeno, J. Frades, and F. Carvalho, Adsorption of landfill leachates onto activated carbon: equilibrium and kinetics. Journal of hazardous materials, 2006. 131(1-3): p. 170-178. 
83. Kumar, K.V., K. Porkodi, and F. Rocha, Comparison of various error functions in predicting the optimum isotherm by linear and non-linear regression analysis for the sorption of basic red 9 by activated carbon. Journal of hazardous materials, 2008. 150(1): p. 158-165.

84. Karaivanova, S. and A. Badev, Modification of polyacrylonitrile fibers with hydrazine and hydroxylamine in aqueous medium. Die Angewandte Makromolekulare Chemie: Applied Macromolecular Chemistry and Physics, 1986. 140(1): p. 1-32.

85. Barsbay, M. and O. Güven, Surface modification of cellulose via conventional and controlled radiation-induced grafting. Radiation Physics and Chemistry, 2019. 160: p. $1-8$.

86. Ye, F., C. Huang, X. Jiang, W. He, X. Gao, L. Ma, J. Ao, L. Xu, Z. Wang, Q. Li, J. Li, and H. Ma, Reusable fibrous adsorbent prepared via Co-radiation induced graft polymerization for iodine adsorption. Ecotoxicology and Environmental Safety, 2020. 203: p. 111021.

87. Nasef, M.M. and E.-S.A. Hegazy, Preparation and applications of ion exchange membranes by radiation-induced graft copolymerization of polar monomers onto nonpolar films. Progress in Polymer Science, 2004. 29(6): p. 499-561.

88. Hegazy, E.-S.A., H.A. AbdEl-Rehim, H. Kamal, and K.A. Kandeel, Advances in radiation grafting. Nuclear Instruments and Methods in Physics Research Section B: Beam Interactions with Materials and Atoms, 2001. 185(1): p. 235-240.

89. Nandiyanto, A.B.D., R. Oktiani, and R. Ragadhita, How to read and interpret FTIR spectroscope of organic material. Indonesian Journal of Science and Technology, 2019. 4(1): p. 97-118.

90. Coates, J., Interpretation of infrared spectra, a practical approach. Encyclopedia of analytical chemistry: applications, theory and instrumentation, 2006. 
Figures

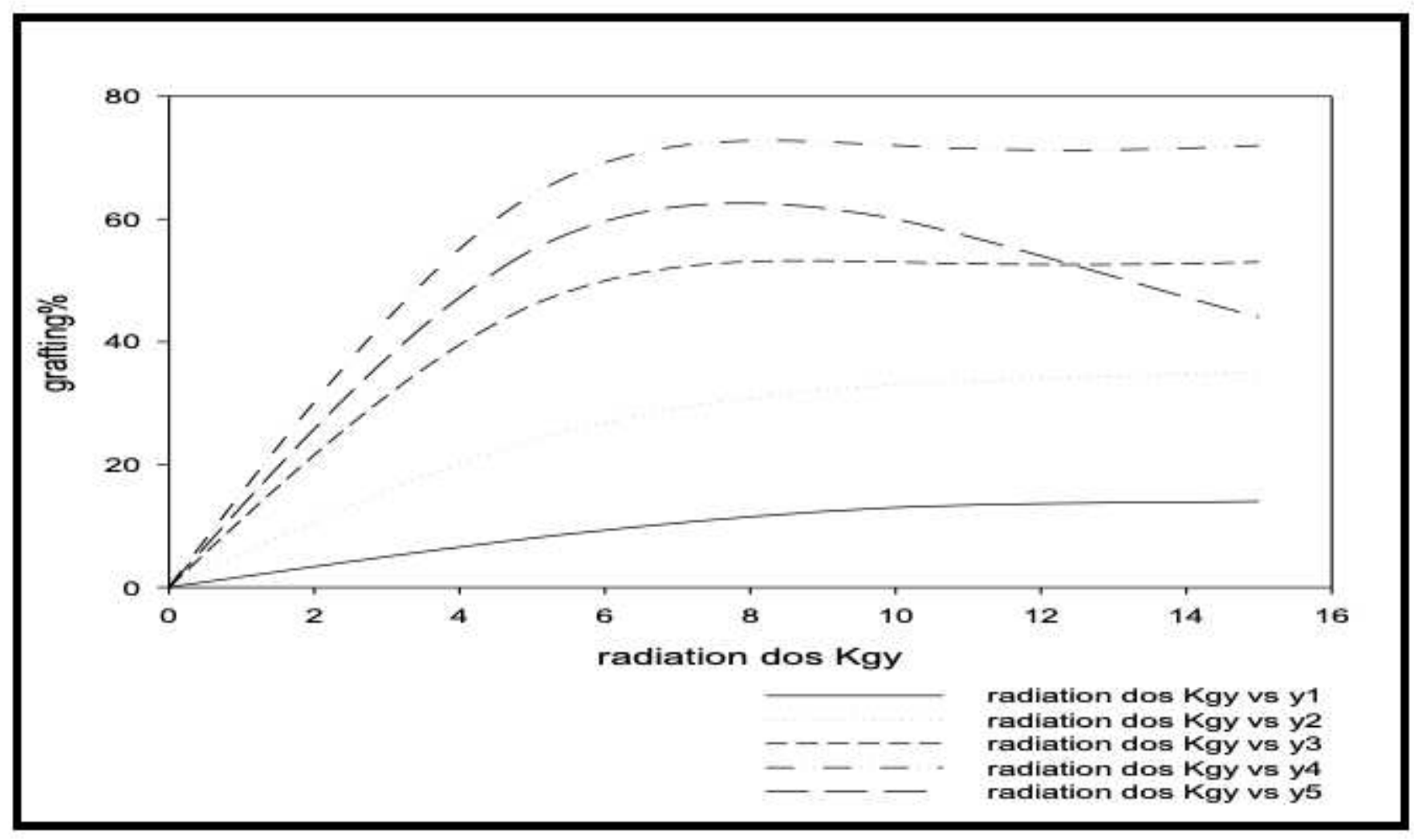

Figure 1

Relationship between grafting \% and radiation dose at different monomer concentration. 


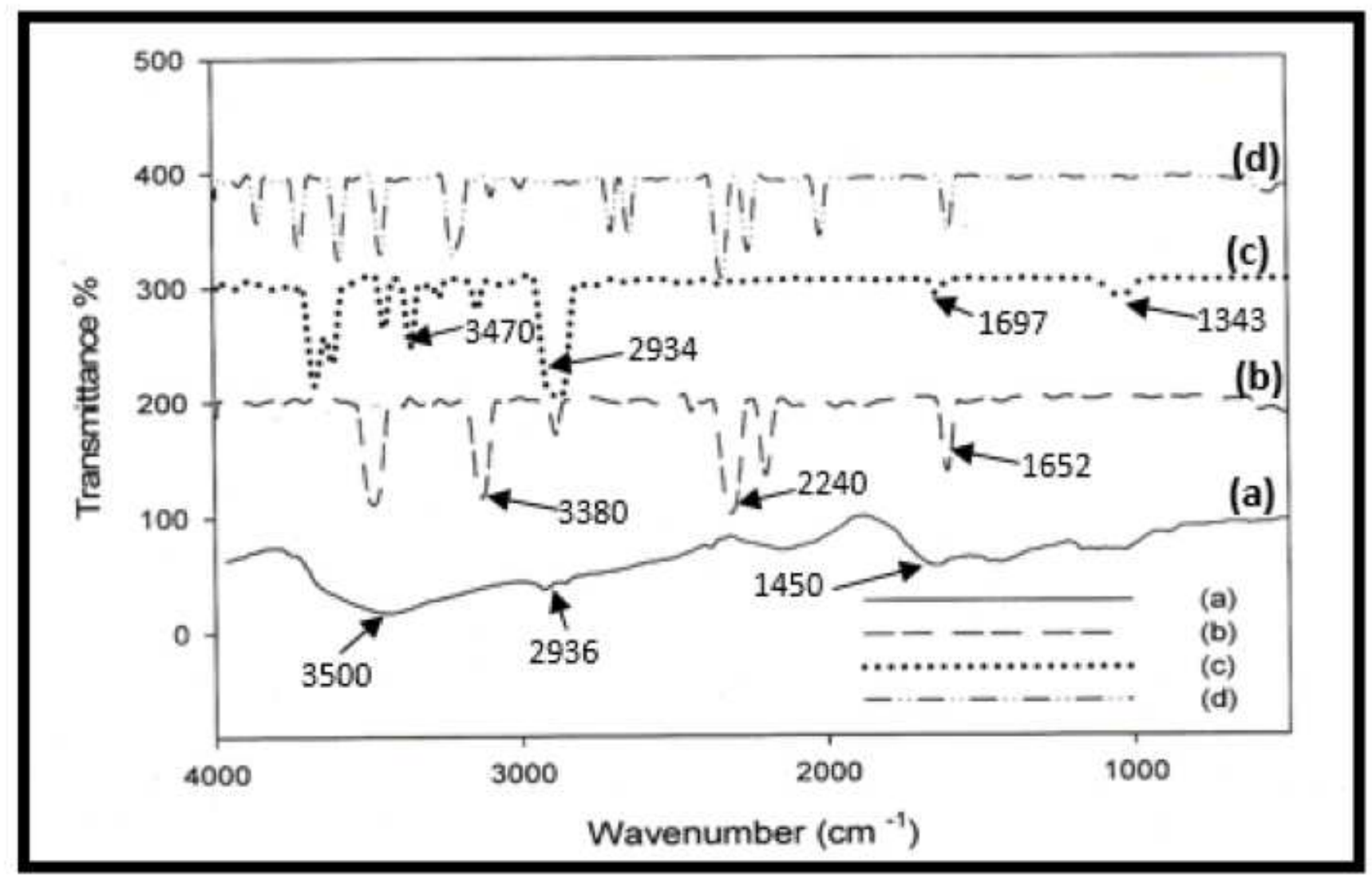

Figure 2

FTIR of cotton fabric (a) AN-g-cotton fabric (b), chemically treated g-fabric with hydrazine hydrate(c) and treated fabric with dimethyl sulfate $(\mathrm{d})$. 


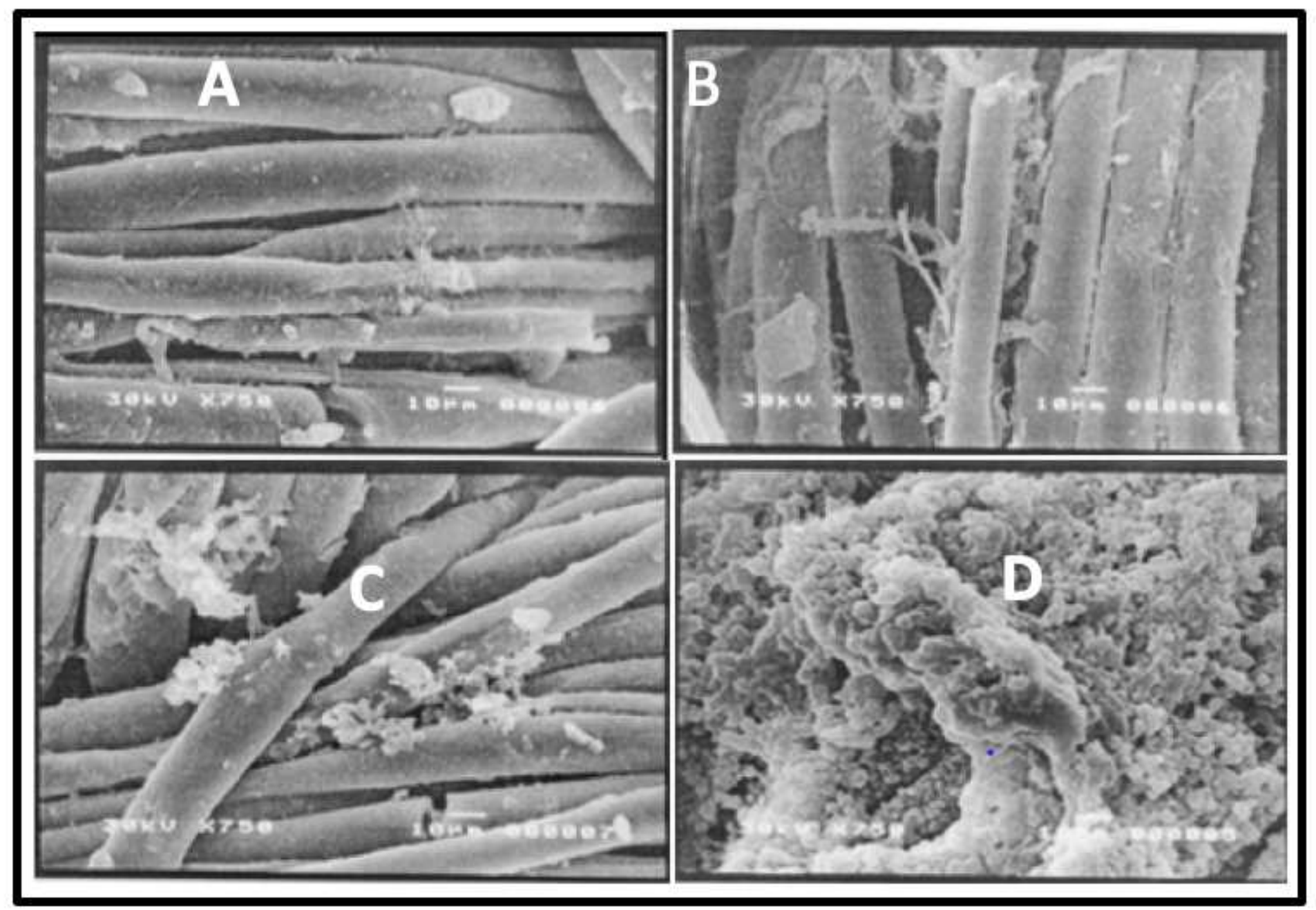

Figure 3

SEM images of (a) unmodified cellulose (b) grafted cellulose (c) hydrazine hydrate modified cellulose (d) dimethyl sulfate modified cellulose
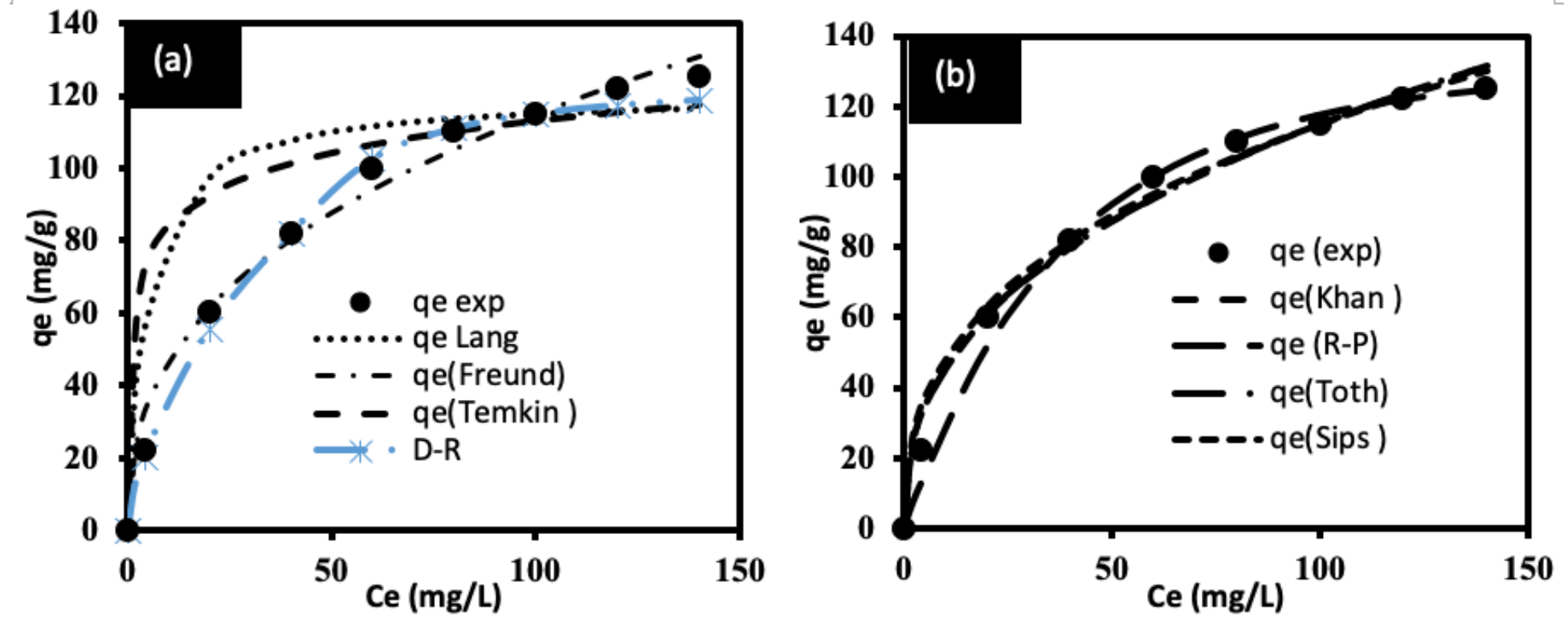
Figure 4

(a) 2-parameter and (b) 3-parameter isotherm plots for nitrate adsorption
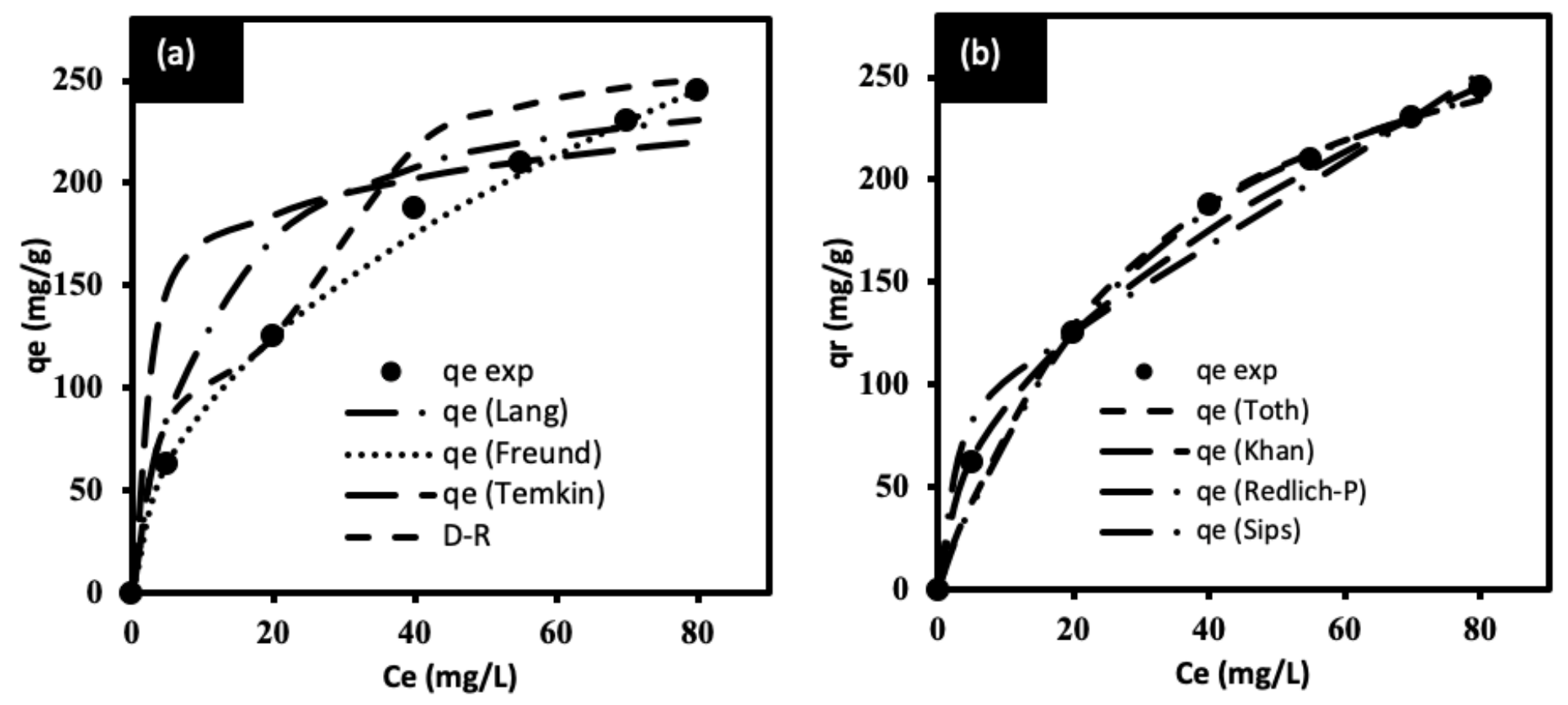

Figure 5

(a) 2-parameter and (b) 3-parameter isotherm plots for phosphate adsorption 